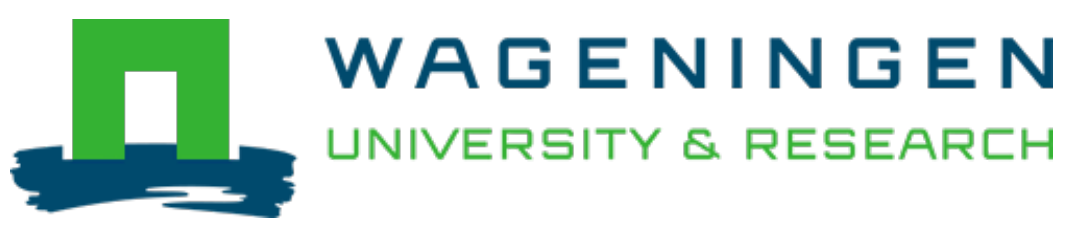

\title{
Commonalities in Symbiotic Plant-Microbe Signalling
}

Advances in Botanical Research

Holmer, R.; Rutten, L.J.J.; Kohlen, W.; Velzen, R.; Geurts, R.

https://doi.org/10.1016/bs.abr.2016.11.003

This article is made publicly available in the institutional repository of Wageningen University and Research, under the terms of article $25 \mathrm{fa}$ of the Dutch Copyright Act, also known as the Amendment Taverne. This has been done with explicit consent by the author.

Article 25 fa states that the author of a short scientific work funded either wholly or partially by Dutch public funds is entitled to make that work publicly available for no consideration following a reasonable period of time after the work was first published, provided that clear reference is made to the source of the first publication of the work.

This publication is distributed under The Association of Universities in the Netherlands (VSNU) 'Article $25 \mathrm{fa}$

implementation' project. In this project research outputs of researchers employed by Dutch Universities that comply with the legal requirements of Article $25 \mathrm{fa}$ of the Dutch Copyright Act are distributed online and free of cost or other barriers in institutional repositories. Research outputs are distributed six months after their first online publication in the original published version and with proper attribution to the source of the original publication.

You are permitted to download and use the publication for personal purposes. All rights remain with the author(s) and / or copyright owner(s) of this work. Any use of the publication or parts of it other than authorised under article $25 \mathrm{fa}$ of the Dutch Copyright act is prohibited. Wageningen University \& Research and the author(s) of this publication shall not be held responsible or liable for any damages resulting from your (re)use of this publication.

For questions regarding the public availability of this article please contact openscience.library@,wur.nl 


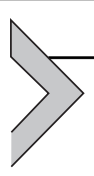

\title{
Commonalities in Symbiotic Plant-Microbe Signalling
}

\author{
R. Holmer ${ }^{a}$, L. Rutten ${ }^{a}$, W. Kohlen, R. van Velzen and R. Geurts ${ }^{1}$ \\ Wageningen University, Wageningen, The Netherlands \\ ${ }^{1}$ Corresponding author: E-mail: rene.geurts@wur.nl
}

\section{Contents}

1. Introduction

2. Intimate Plant Root-Microbe Symbioses 2

2.1 Mycorrhizal Symbioses 3

2.2 Nitrogen-Fixing Endosymbioses 5

3. Recognition and Attraction of Symbiotic Partners 7

3.1 Flavonoids Induce Microbial Responses 7

$\begin{array}{ll}3.2 \text { Dual Role of Strigolactones } & 10\end{array}$

4. A Conserved Signalling Pathway for Endosymbioses 14

$\begin{array}{ll}4.1 \text { LCO Signalling } & 15\end{array}$

$\begin{array}{ll}4.2 \text { Bypassing LCO Signalling } & 18\end{array}$

5. Repressing Immunity 20

6. Perspectives in Symbiotic Signalling 22

Acknowledgements $\quad 23$

References $\quad 24$

\section{Abstract}

Plants face the problem that they have to discriminate symbionts from a diverse pool of soil microbes, including pathogens. Studies on different symbiotic systems revealed commonalities in plant-microbe signalling. In this chapter we focus on four intimate symbiotic interactions: two mycorrhizal ones, with arbuscular- and ectomycorrhizal fungi, and two nitrogen-fixing ones, with rhizobium and Frankia bacteria. Comparing these systems uncovered commonalities in the way plants attract their symbiotic partners. Especially flavonoids, and in a lesser extent strigolactones, are pivotal plant signals that are perceived by the microsymbiont. In response, signal molecules are exuded by the microbes to trigger symbiotic responses in their host plant. Strikingly, microbes that establish an endosymbiotic relation with their host plant, namely arbuscular mycorrhizal fungi, rhizobium and Frankia bacteria, make

a Authors contributed equally. 
use of a symbiotic signalling network that is highly conserved in plants. The use of flavonoids as attractants for symbiotic microbes, in combination with the use of a common plant signalling network to establish endosymbioses, raises questions about how plants manage to discriminate their microbial partners.

\section{INTRODUCTION}

High throughput sequencing approaches have uncovered an overwhelming diversity of soil microbes. Plants affect this microbial community - directly or indirectly - with their root systems. For example, roots exude substantial amounts of organic and amino acids, polymerized sugars (e.g., mucilage) as well as release border cells and dead root cap cells, which all form a nutrient source for many microbes (Jones, Nguyen, \& Finlay, 2009). On top of that more specific secondary metabolites are exuded that manipulate the microbial community by acting as antimicrobial agent or as attractant. Conversely, soil microbes can affect plant growth. For example, microbes can promote plant growth by improving nutrient availability or inducing resistance against biotic and abiotic stresses (Coleman-Derr \& Tringe, 2014; Mendes, Garbeva, \& Raaijmakers, 2013). On the other hand, pathogenic microbes can induce resource loss and disease. In this complex plant root microbiome network the plant must therefore discriminate between bacteria and fungi that provide an advantage and those that act as commensals or even pathogens. In this chapter we will focus on the molecular communication in a symbiotic context which occurs in plant roots and the rhizosphere. Plants establish several intricate long-term mutualistic relationships with microbes that are hosted intercellularly (ecto) or intracellularly (endo). Here, we will discuss the commonalities of four intimate symbiotic interactions. Thereby we will focus on two key stages of the interaction: attraction of the microbial partner and subsequent microbe-induced signalling to establish a symbiosis.

\section{INTIMATE PLANT ROOT-MICROBE SYMBIOSES}

Plant root symbioses occur at different levels of engagement, ranging from loosely attached microbes that provide a certain advantage to the plant to bacteria that are intracellularly accommodated as organelle-like structures (Mendes et al., 2013; Van Loon, 2007). The best studied plant root symbioses are those with arbuscular mycorrhizal and ectomycorrhizal 
fungi and those with rhizobium and Frankia nitrogen-fixing bacteria, together encompassing a diverse range of plant and microbial species.

\subsection{Mycorrhizal Symbioses}

Mycorrhizal symbioses - the symbiotic interactions between some soil fungi and plant roots - can occur in several forms. Of these the ancient arbuscular (endo) mycorrhiza and the much younger forms of ectomycorrhiza are best studied.

Based on fossil records arbuscular mycorrhizal symbiosis is estimated to be at least $\sim 400-460$ million years old, and evolved in a period that coincides with colonization of terrestrial habitats by plants (Redecker, Kodner, \& Graham, 2000; Remy, Taylor, Hass, \& Kerp, 1994; Simon, Bousquet, Levesque, \& Lalonde, 1993). Still today the vast majority of land plant species establish an arbuscular mycorrhizal symbiosis, underlining the ecological importance of this interaction (Wang \& Qiu, 2006). The fungi that establish an arbuscular mycorrhizal symbiosis belong to a distinct taxonomic phylum, the Glomeromycota. This phylum possibly represents more than 1000 species, though only less than 300 have been characterized to a certain level of detail (Redecker et al., 2013). Arbuscular mycorrhizal fungi are obligate biotrophs. Their hyphae penetrate plant roots intercellularly and form intracellular feeding structures - called arbuscules - in root cortical cells (Fig. 1A). Arbuscules are surrounded by a plant-derived membrane, but are largely deprived of plant cell wall material (Balestrini \& Bonfante, 2014). At this symbiotic interface nutrients are exchanged. Minerals - especially phosphates and nitrates - taken up by the fungal extraradical mycelium are delivered to the plant in return for carbohydrates. Arbuscules remain functional for several days, after which they collapse and disappear, leading to a reversion of the plant cell to its asymbiotic cortical fate.

Ectomycorrhizal symbiosis can occur between diverse groups of plant and fungal species, as a result of several independent evolutionary events (Martin et al., 2016). Overall this type of symbiosis can occur in about $2 \%$ of all land plants, including all dominant tree species in temperate forests, such as pines (Pinus), Douglas firs (Pseudotsuga), oaks (Quercus), willows (Salix), beeches (Fagus) and birches (Betula) (Smith \& Read, 2008; Tedersoo, May, \& Smith, 2010). Ectomycorrhizal fungi belong to several taxonomic phyla including Basidiomycota, Ascomycota and Zygomycota (Tedersoo \& Smith, 2013) which are all closely related to species with a saprotrophic lifestyle. Saprophytic fungi have an extensive repertoire of genes encoding 
(A)

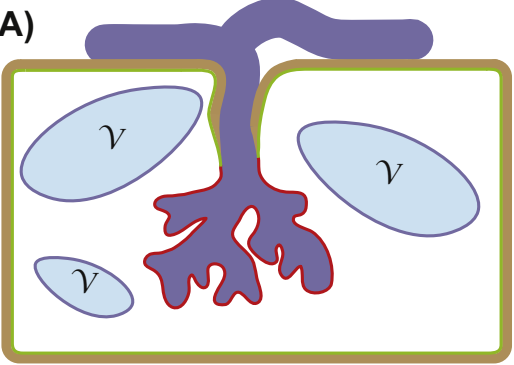

(C)

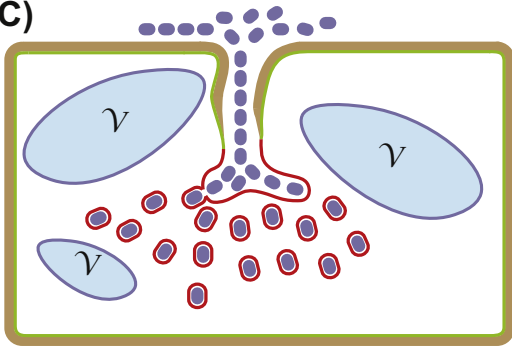

(B)

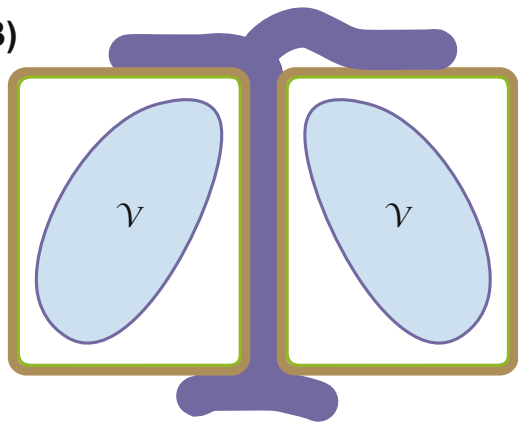

(D)

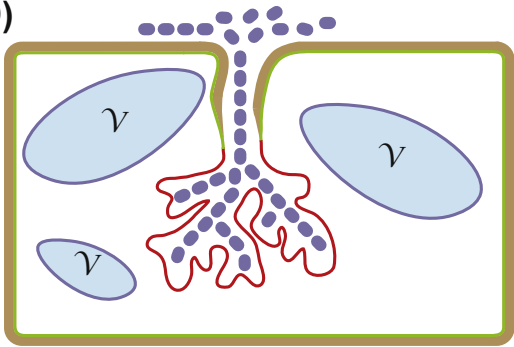

Figure 1 Schematic representation of the cellular mode of infection of the four symbioses discussed in this chapter. Green lines indicate plant cell membrane, red lines indicate the plant cell membrane-derived symbiotic interface in the form of the periarbuscular membrane for arbuscular mycorrhizal, symbiosomes for rhizobium/ legumes and fixation threads for Frankia/actinorhizal plants and for rhizobium/Parasponia. (A) Hyphae of an endomycorrhizal fungus penetrating the cell and forming a feeding structure named arbuscule. Arbuscules are not surrounded by a plant-derived cell wall. (B) Hyphae of an ectomycorrhizal fungus growing intercellularly. (C) Rhizobium bacteria released within transient organelle-like structures - named symbiosomes - in nodule cells of most legumes. (D) Frankia in actinorhizal plants and some rhizobia in Parasponia and in some basal legumes infect cells of nodules through fixation threads. Fixation threads are largely deprived of plant cell wall. The bacteria in fixation threads remain in contact with the apoplast. Blue: vacuole (v); purple: microbe; brown: plant cell wall; green: plant plasma membrane; red: plant-derived endosymbiotic membrane.

degrading enzymes that can effectively mobilize resources, in particular nitrogen and phosphorus, from a variety of organic substrates (Plett \& Martin, 2011). However, compared to their saprophytic sister clades, ectomycorrhizal fungi only have a limited set of genes encoding plant cell wall-degrading enzymes (e.g., pectin lyases and pectinases) (Kohler et al., 2015). Nevertheless, expression studies indicate that some of the plant cell wall-degrading enzymes that have been maintained may function during symbiosis (Balestrini \& Bonfante, 2005). 
Despite the diverse and paraphyletic groups of plant and fungal species that establish ectomycorrhizal symbioses, there is a remarkable resemblance in symbiotic phenotypes. The fungi preferentially colonize newly formed lateral roots. Upon hyphal attachment, they modulate root growth which allows them to colonize the root apoplast, forming a so-called Hartig net. The penetration depth of the hyphae is variable, but it typically comprises several layers of cortical cells, excluding the endodermis. In contrast to the endomycorrhizal symbiosis, root cells are not invaded intracellularly (Fig. 1B). Ultimately, many fungal hyphae cover the root surface forming a thick, multilayered 'mantle', insulating the infected lateral root. The molecular mechanisms underlying Hartig net development remain elusive. In 2015, using a combination of genome sequencing and reverse genetic studies, have provided new insights into the early symbiosis signalling. For example, in the fungus Laccaria bicolor, it was found that an aquaporin (LbAQP1) is essential for Hartig net development and the expression of effector genes. LbAQP expression is triggered upon direct root contact and functions as a transport facilitator for plant-signalling molecules, most likely $\mathrm{H}_{2} \mathrm{O}_{2}$, $\mathrm{NO}$ or $\mathrm{CO}_{2}$ (Navarro-Rodenas, Xu, Kemppainen, Pardo, \& Zwiazek, 2015). Additionally L. bicolor produces auxin (IAA) in its mycelium that triggers auxin-related responses in the plant root (Vayssières et al., 2015). This finding is in line with pioneer work that showed that increased mycorrhizal activity is associated with increased auxin biosynthesis by the fungus (Gea, Normand, Vian, \& Gay, 1994). Together, these studies make clear that plant-fungal signalling intertwines with plant auxin homoeostasis and possibly used reactive oxygen species to establish a symbiotic interaction.

\subsection{Nitrogen-Fixing Endosymbioses}

A selective, though diverse, group of plant species is able to establish an endosymbiosis with nitrogen-fixing (diazotrophic) bacteria. These bacteria belong either to the genus Frankia or to the paraphyletic group of bacteria known as rhizobia. Frankia and rhizobia strains gained the symbiotic trait by horizontal gene transfer.

The genus Frankia is a diverse assemblage of filamentous sporangiaforming actinobacterial species that can be saprophytic, facultative symbiotic or obligatory symbiotic. The Frankia genus can be separated in four separate bacterial clusters based on phylogenetic analysis, with only three of them that can establish symbiosis (Gtari, Tisa, \& Normand, 2013). Plant species that can form a nitrogen-fixing endosymbiosis with 
Frankia bacteria ( $\sim 230$ species known as actinorhizal plants) are dispersed over 25 genera and 8 taxonomic families, suggesting multiple evolutionary origins of this symbiosis (Pawlowski \& Demchenko, 2012).

Relative to Frankia, rhizobia are even more diverse, representing 15 genera in 8 families of $\boldsymbol{\alpha}$-, $\boldsymbol{\beta}$ - and $\boldsymbol{\gamma}$-Proteobacteria (Remigi, Zhu, Young, \& Masson-Boivin, 2015). Nitrogen-fixing symbiosis with rhizobia is prominent in the legume family (Fabaceae), but can also occur in Parasponia, a genus in the Cannabis family (Cannabaceae). Based on the phylogenetic distance between Fabaceae and Cannabaceae it is most probable that - similarly to the actinorhizal symbiosis - there are multiple origins for rhizobial symbiosis (Behm, Geurts, \& Kiers, 2014; Geurts, Lillo, \& Bisseling, 2012). The formation of specific nodule-like structures (root nodules) by the host plant, in which the bacteria proliferate and fix nitrogen, is common for both types of endosymbiosis with diazotrophic bacteria.

The reason for this may be that rhizobia and Frankia bacteria are generally not able to infect differentiated cells of the plant root. Only cells of the future nodule that are mitotically activated by the microsymbiont can be infected, suggesting that these cells are developmentally reprogrammed (Geurts, Xiao, \& Reinhold-Hurek, 2016). The nodules are optimized to facilitate growth of the microbial partner, which, once inside nodule cells, differentiates in its symbiotic form and fixes atmospheric nitrogen into ammonia in exchange for carbohydrates.

Variation exists in the way the nitrogen-fixing bacterial partner is hosted. In most legume nodules, rhizobia are hosted in transient organelle-like structures, called symbiosomes. Symbiosomes are released from intracellular infection threads that have guided the rhizobium bacteria from the epidermis towards the newly formed nodule. Hundreds of symbiosomes surrounded by a plant-derived membrane, often containing only one bacterium, can be present in a single nodule cell. This membrane forms a symbiotic interface where nutrient exchanges take place between the bacteria and the cytoplasm of the host cell (Fig. 1C). In Parasponia and actinorhizal plants symbiosomes are not formed. Instead, the bacteria remain in threadlike structures, known as fixation threads (Fig. 1D). Fixation threads differ from the penetrating infection thread by a reduction of plant cell wall material. Fixation threads also occur in a few legume species and may represent a more ancestral form of bacterial endosymbiosis than symbiosomes (Behm et al., 2014).

Of the four intimate symbiotic interactions that are central here, three have evolved more than once: the symbioses with rhizobia, Frankia and 
ectomycorrhizal fungi. This suggests an evolutionary advantage of root symbiosis for both partners. Interestingly, several studies indicate that similar mechanisms have been coopted in all four symbiotic interactions. Later we will discuss the commonalities in signalling mechanisms between the four symbioses central in this chapter.

\section{RECOGNITION AND ATTRACTION OF SYMBIOTIC PARTNERS}

As outlined earlier, not all plants are able to form an intricate root microbe symbiosis; nor are all soil microbes symbiotic. Consequently, symbiotic partners need to recognize each other. Microbes recognize potential host plants by root exudates. Indeed, plants can exude signalling molecules to attract their symbiotic partner. Common signals in symbiotic partner recognition are exuded flavonoids, which play a role in all four symbioses. In addition, it was noted that exuded strigolactones can act as signal molecules, especially in arbuscular mycorrhizal symbiosis. Strikingly, both types of molecules function also as endogenous plant signals.

\subsection{Flavonoids Induce Microbial Responses}

Flavonoids are a subclass of plant polyphenolic compounds and are a major class of secondary metabolites. As is typical for plant secondary metabolites, flavonoids are diverse; $\sim 9000$ chemical structures have so far been reported (Ferrer, Austin, Stewart, \& Noel, 2008). Flavonoids are synthesized through the phenylpropanoid pathway. A chalcone synthase produces the chalcone scaffolds from which all other flavonoids are derived and is the first enzyme specific for flavonoid production (Falcone Ferreyra, Rius, \& Casati, 2012). A series of enzymatic reactions can alter the chalcone scaffold into a huge diversity of compounds. Flavonoids are typically categorized in subclasses based on these enzymatic reactions. The major subclasses of flavonoids include phlobaphenes, flavones, flavanones, flavonols, aurones, isoflavonoids, anthocyanins and condensed tannins. Many flavonoids are known to have glycosidated forms, i.e., quercitrin is formed by the addition of the deoxy sugar rhamnose to the flavonol quercetin, whereas rutin is formed by the addition of the disaccharide rutinose. Such small modifications can have drastic consequences for the observed effects in symbioses.

The involvement of flavonoids in symbioses has been described for all four types of symbiosis discussed in this review (arbuscular mycorrhizal, ectomycorrhizal, rhizobial and actinorhizal symbioses). For two compounds 
positive effects in all four symbioses have been described (Fig. 2). Naringenin positively influences arbuscular mycorrhizal colonization (Garg \& Singla, 2016) and rhizobium symbiosis (Weston \& Mathesius, 2013), enhances spore germination of the ectomycorrhizal fungus Suillis bovinus (Kikuchi, Matsushita, Suzuki, \& Hogetsu, 2007) and restores Frankia nodulation in a chalcone synthase mutant of the actinorhizal plant Casuarina glauca (Abdel-Lateif et al., 2013). Quercetin has been reported to stimulate spore germination, hyphal branching and growth of arbuscular mycorrhizal fungi (Bécard, Douds, \& Pfeffer, 1992; Tsai \& Phillips, 1991), the growth rate of rhizobium bacteria (Hartwig, Joseph, \& Phillips, 1991), the actinorhizal nodulation (Sayed \& Wheeler, 1999) and it also stimulates the production of the symbiotic effector protein MiSSP7 in the ectomycorrhizal fungus L. bicolor (Plett \& Martin, 2012).

The molecular mode of action of naringenin and quercetin is not always known. Best studied is the effect of naringenin - and other flavonoids - in rhizobia, where flavonoids target NodD proteins. Rhizobial NodD proteins belong to the class of LysR-type transcriptional regulators that are activated upon the binding of external signals (Honma, Asomaning, \& Ausubel, 1990; Mulligan \& Long, 1989). Binding of a flavonoid molecule causes a conformational change which results in an increased binding affinity for specific

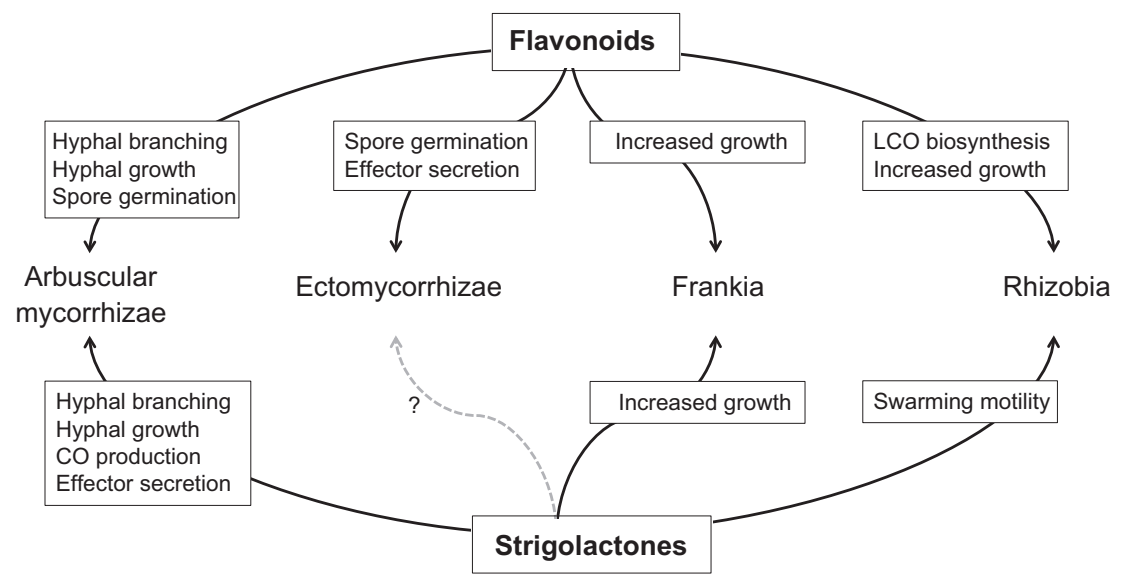

Figure 2 Flavonoids and strigolactones are generic attractants for microsymbionts. For now it remains unclear whether strigolactones have a direct effect on ectomycorrhizal symbiosis. Increased growth of Frankia can possibly be attributed to either flavonoids, strigolactones or even other components as total root exudates were used to demonstrate this (Beauchemin et al., 2012). COs, chito-oligosaccharides; LCOs, lipochito-oligosaccharides. 
cis-regulatory elements. In case of NodD this element is known as the nod box (Chen et al., 2005). Rhizobia generally have several operons that contain a nod box in their promoter region. Most prominent are the genes encoding an ABC transporter (NodI and NodJ) and three genes encoding the enzymes $N$-acetylglucosaminyltransferase (NodC), a chitooligosaccharide deacetylase (NodB) and an $N$-acyltransferase (NodA). These proteins are essential for biosynthesis and secretion of lipo-chito-oligosaccharide molecules (LCOs), which act as potent symbiotic signal molecules (see Section 4) (Limpens, van Zeijl, \& Geurts, 2015; Oldroyd, 2013).

In case of arbuscular mycorrhizae and Frankia it remains elusive whether flavonoids trigger biosynthesis of similar symbiotic signalling molecules, despite the fact that flavonoids have a positive effect on both symbioses (Auguy et al., 2011; Garg \& Singla, 2016). LCOs and short-chain chitin oligomers (tetra and pentameric COs) have been shown to be produced by the mycorrhizal fungus Rhizophagus irregularis, but their biosynthetic pathways have not yet been uncovered (Genre et al., 2013; Lin et al., 2014; Maillet et al., 2011; Tisserant et al., 2013). In case of symbiotic Frankia species, LCO biosynthesis genes are not common, and only found in a representative of a relatively isolated taxonomic lineage (cluster 2): namely (candidatus) Frankia datiscae strain DG1 (Persson et al., 2015). For this strain it was found that $\operatorname{nod} A, \operatorname{nod} B$, nodC, nodI and nodJ are expressed when the bacteria occupy Datisca glomerata root nodules (Beauchemin et al., 2012). Therefore, it is most probable that F. datiscae LCO signals play a symbiotic role.

Other flavonoids have been described to be involved in one or a few of the discussed symbioses, but were never tested in the other types of symbioses. Nevertheless, these observations can shed an interesting light on the symbiotic role of flavonoids. Especially interesting is the described host specificity in the legume rhizobia interaction (Reddy, María, \& Soto, 2007), which in part is determined by recognition of specific flavonoids. Whereas a specific flavonoid can induce expression of the LCO biosynthetic nod $A B C$ operon in one bacterium, the same compound can have a negative effect in another bacterium. For example, the flavonoid coumestrol positively influences the symbiosis between Glycine max and Sinorhizobium fredii USDA191 (Kosslak, Bookland, Barkei, Paaren, \& Appelbaum, 1987) but negatively influences the symbiosis between Medicago sativa and Sinorhizobium meliloti 1021 (Zuanazzi et al., 1998). In this context, it is also relevant to note that the composition of root exudates may vary depending on the developmental stage of the root. For example, studies in $M$. sativa indicate 
that flavonoids with a positive effect on the symbiosis are exuded in the elongation and differentiation zone that is susceptible to rhizobium infection. Whereas repelling flavonoids are exuded in the adjacent regions of the root (i.e., the root tip and the more mature part of the root) (Peters \& Long, 1988; Zuanazzi et al., 1998). However, such studies have not been further extended to see whether similar mechanisms exist in other nodulating taxa.

In addition to direct application of flavonoids to microbial cultures, reverse genetic studies in plants have been conducted. In most studies chalcone synthase genes were targeted. Chalcone synthase knockdown in actinorhizal C. glauca, or in the legume model Medicago truncatula results in impaired nodulation (Abdel-Lateif et al., 2013; Wasson, Pellerone, \& Mathesius, 2006). In both plant systems this phenotype can be restored by the application of naringenin. In contrast, no effect was reported on the arbuscular mycorrhizal symbiosis when using a chalcone-synthase doublemutant in maize (Bécard, Taylor, Douds, Pfeffer, \& Doner, 1995). The fact that a chalcone synthase maize mutant can be normally mycorrhizal with different fungal species demonstrates that flavonoids are not essential signals for this symbiosis. Nevertheless, flavonoids may act as facultative signals, and may play a role in host selection, by activating certain fungi over others (Ellouze et al., 2012).

The importance of flavonoids in root nodule symbiosis may be the result of the fact that flavonoids also act as endogenous plant signals that control auxin transport (Brown et al., 2001; Mathesius et al., 1998; Wasson et al., 2006). Based on quantitative modelling and experimental studies it is hypothesized that a transient decrease in auxin efflux can lead to formation of a local auxin maximum, which is the onset of nodule development (Deinum, Geurts, Bisseling, \& Mulder, 2012; Hirsch, Bhuvaneswari, Torrey, \& Bisseling, 1989). Such a function of flavonoids in nodulation is supported by the finding that naringenin can restore nodulation in the M. truncatula cytokinin signalling mutant Mtcre1 ( $\mathrm{Ng}$, Perrine-Walker, Wasson, \& Mathesius, 2015). This study demonstrates that naringenin not only acts as an attractant of symbiotic microbes, but also functions as an endogenous plant signal, which - in a symbiotic context - acts downstream, or in parallel, to rhizobium-induced cytokinin signalling.

\subsection{Dual Role of Strigolactones}

Strigolactones are carotenoid-derived terpenoid lactones, often composed of four rings. Three rings form a tricyclic lactone, which is connected to the 
fourth butenolide ring via an enol ether bridge (Pandey, Sharma, \& Pandey, 2016). Strigolactones are known as endogenous plant hormones that control several steps in plant development (Brewer, Koltai, \& Beveridge, 2013). Since the discovery of their function in the regulation of shoot branching in 2008, major advances have been made on the identification of the strigolactone biosynthesis and perception pathway. A carotenoid isomerase [named DWARF27 (D27) in most species], two carotenoid cleaving dioxygenases (named CCD7 and CCD8), and a cytochrome P450 (possibly MAX1 in Arabidopsis thaliana) are sequentially required to produce the strigolactone backbones: either 4-deoxyorobanchol or 5-deoxystrigol (Alder et al., 2012; Zhang et al., 2014). It is postulated that this backbone can be further decorated to produce the wealth of different strigolactone metabolites (Al-Babili \& Bouwmeester, 2015). In plants the strigolactone receptor was identified as an $\alpha / \beta$ hydrolase [named OsDWARF14 (D14) in rice (Oryza sativa) and AtDAD2 in A. thaliana]. Together with a specific F-box protein named OsDWARF3/AtMAX2 it forms the SCF E3 ubiquitin ligase complex required for strigolactone signalling (Hamiaux et al., 2012; Zhao et al., 2015).

The discovery that strigolactones stimulate hyphal branching in the arbuscular mycorrhizal fungus Gigaspora margarita (Akiyama, Matsuzaki, \& Hayashi, 2005) has launched an interest in the involvement of these compounds in symbiotic signalling. The observation that strigolactones induce hyphal branching in G. margarita - at very low concentrations has led to the hypothesis that the induction of hyphal branching must be receptor mediated (Akiyama, Ogasawara, Ito, \& Hayashi, 2010). Furthermore, it was found that the synthetic strigolactone analog GR24 triggers mitochondrial activity in the arbuscular mycorrhizal fungi Rhizophagus intraradices and Gigaspora rosea (Besserer et al., 2006). However, it should be noted that to induce hyphal branching in G. rosea besides GR24, also the flavonoid quercetin is needed in the fungal growth medium (Besserer, Bécard, Jauneau, Roux, \& Séjalon-Delmas, 2008). As quercetin is known to stimulate arbuscular mycorrhizal growth, hyphal branching and spore germination (Tsai \& Phillips, 1991) this suggests that with this specific fungus strigolactones alone might not be sufficient to induce hyphal branching. In an independent experiment increased production of shortchain COs upon application of GR24 was reported for $R$. irregularis (Genre et al., 2013) (Fig. 2). In addition, a putative effector protein (RiSIS1) was identified in a screening of upregulated genes in GR24-treated $R$. irregularis (Tsuzuki, Handa, Takeda, \& Kawaguchi, 2016). Using host-induced gene 
silencing the RiSIS1 gene was knocked down during infection, which resulted in significant suppression of colonization and stunted arbuscules. This suggests that RiSIS1 is a strigolactone-induced effector protein.

Application of GR24 to four ectomycorrhizal species revealed no effect on hyphal branching (Steinkellner et al., 2007) (Fig. 2). This suggests strigolactones play a less important or different role in this type of symbiosis. In contrast, a negative effect of GR24 was observed on growth and branching of a range of phytopathogenic fungi (Dor, Joel, Kapulnik, Koltai, \& Hershenhorn, 2011), including species previously found not to be affected by GR 24 (Steinkellner et al., 2007). It should be noted that these effects were only observed when relatively high concentrations of GR24 were used (Dor et al., 2011) and as such it remains unclear whether these concentrations were biologically relevant.

Apart from the beneficial effects in arbuscular mycorrhizal symbiosis, several studies revealed effects of strigolactones in the rhizobium/legume symbiosis (Fig. 2). Exogenous application of GR24 increases $M$. sativa nodule number when inoculated with S. meliloti (Soto et al., 2010). Interestingly, the same study reports that the bacterial growth and nodC expression are not affected by GR24, leading the authors to hypothesize that the effect of GR24 is on the plant. However, more recently it was suggested that GR24 might affect S. meliloti by promoting bacterial swarming motility (Peláez-Vico, Bernabéu-Roda, Kohlen, Soto, \& López-Ráez, 2016). In an independent experiment in $M$. truncatula low concentrations $(0.1 \mu \mathrm{M})$ of GR24 also resulted in increased nodule numbers, but higher concentrations $(2-5 \mu \mathrm{M})$ resulted in reduced nodule numbers and lateral root density (De Cuyper et al., 2014). Taken together this suggests that strigolactones act mainly as plant hormones involved in developmental programs during rhizobial symbiosis. In line with this, the strigolactone biosynthesis gene $M t D 27$ was shown to be inducible by rhizobium LCOs $3 \mathrm{~h}$ after application and that this induction is regulated by the common symbiotic signalling pathway (Van Zeijl et al., 2015).

Mutants and knockdown experiments of strigolactone biosynthesis genes in several species shed light on the dual role of strigolactones in symbioses. Whereas often symbiotic phenotypes are observed, it is not trivial to decide whether these phenotypes are an effect of a change in direct signalling between host and symbiont, or whether a change in hormonal balance causes a difference in plant developmental program. CCD are among the most studied strigolactone biosynthetic enzymes in a symbiotic context. Mutation or knockdown of $c c d 7 / 8$ in several plant 
species results in reduced mycorrhizal colonization (Gomez-Roldan et al., 2008; Kohlen et al., 2012; Kretzschmar et al., 2012; Liu et al., 2013; Vogel et al., 2010). In addition, nodulation was reported to be impaired in the Lotus japonicus CCD7 knockdown and both $c c d 7$ and $c c d 8$ mutants of pea (Foo, Yoneyama, Hugill, Quittenden, \& Reid, 2013; Liu et al., 2013). The importance of strigolactones in mycorrhizal colonization is further supported by the identification of a strigolactone transporter in Petunia $x$ hybrida. The knockout of the ABC transporter PhPDR1 resulted in significantly reduced orobanchol levels in root exudates, which had effects on $G$. margarita and $R$. irregularis mycorrhization efficiency. Plants show reduced colonization due to reduced mycorrhizal growth, branching and spore germination (Kretzschmar et al., 2012). The GRAS transcriptional regulators NSP1 and NSP2 were identified as regulators of strigolactone biosynthesis in rice and $M$. truncatula by regulating D27 expression (Liu et al., 2011). M. truncatula nsp 1 and nsp 2 mutants are not capable of forming nodules (Catoira et al., 2000; Oldroyd \& Long, 2003). The nsp 1 mutant and the nsp1/nsp2 double mutant produce no detectable amounts of strigolactones, whereas the nsp 2 mutant has a reduced and different strigolactone composition. Interestingly, mycorrhizal colonization of the nsp 1/ $n s p 2$ double mutant by $R$. irregularis was only mildly reduced (Liu et al., 2011). In addition, the L. japonicus nsp 1 mutant is unable to form nodules; however, infection by the arbuscular mycorrhizal fungus $R$. irregularis was unaffected (Heckmann et al., 2006).

The rice and pea F-box mutants Osd3/Psrms 4 are markedly reduced in mycorrhizal colonization (Foo et al., 2013; Yoshida et al., 2012). This suggests that strigolactone perception in planta plays a role in arbuscular mycorrhizal colonization. Strikingly, in the pea Psrms4 mutant nodule numbers are increased (Foo et al., 2013), indicating that the effect of strigolactones in nodulation is regulated differently compared to mycorrhization.

Interestingly, a severe mycorrhization phenotype in rice could be complemented by introducing a copy of OsD14-LIKE gene (Gutjahr et al., 2015). OsD14-Like is paralogous to OsD14 and has strong similarities with the $A$. thaliana karrikin receptor $A t K A I 2$, which is responsible for detecting the smoke compound karrikin. OsD14 and OsD14-LIKE have been reported to have partially overlapping, but also distinct, functions for strigolactone and karrikin responses, as the Atkai2 mutants are insensitive to karrikins but weakly responsive to strigolactones (Scaffidi et al., 2014). In addition, it was recently demonstrated that in $A$. thaliana AtD14 and AtD14-like have different affinities for specific strigolactone 
stereoisomers (Scaffidi et al., 2014). This could indicate that the perception of specific strigolactones is regulated by multiple receptor complexes.

Taken together, the involvement of strigolactones in arbuscular mycorrhiza symbiosis is relatively well described, although several details remain unclear. A possible involvement in rhizobial symbiosis is just starting to be discovered. However, given the distinct nature of both symbioses, the mechanisms by which strigolactones functions are likely different between the two. For ectomycorrhizal and actinorhizal symbioses, no clear data on the involvement of strigolactones is available yet. As strigolactones are plant hormones involved in key developmental processes, it is not surprising that ectomycorrhizal hosts were found to possess the strigolactone biosynthetic genes (Garcia, Delaux, Cope, \& Ane, 2015).

\section{A CONSERVED SIGNALLING PATHWAY FOR ENDOSYMBIOSES}

As mentioned earlier, arbuscular mycorrhizal fungi, rhizobia and some basal Frankia species produce LCO signals in a symbiotic context, whereas no evidence has been found that LCO signals are playing a role in ectomycorrhizal symbiosis. This suggests that LCO signalling is a feature of microbes that establish an endosymbiosis rather than an ectosymbiosis.

LCOs are prominent signal molecules that are perceived by the host plant and set in motion symbiotic responses. Genetic studies in legumes, rice, Parasponia and the actinorhizal plant species Datisca glutinosa (nodulated by Frankia sp. harbouring LCO biosynthesis genes), but also in C. glauca, a species that is nodulated by Frankia sp. that lack LCO biosynthesis genes uncovered a common symbiotic signalling network. This conserved symbiotic network stretches from transmembrane receptor kinases to a network of transcription factors that control the readout of symbiotic signalling (Oldroyd, 2013). A hallmark of endosymbiotic signalling is the induction of regular oscillations of the nuclear calcium concentration. To achieve this a complex of nuclear envelope-localized proteins are essential, including a potassium-permeable channel (encoded by MtDMI1, LjCASTOR, LjPOLLUX), a cyclic nucleotide-gated calcium channel and a calcium ATPase (Capoen et al., 2011; Charpentier et al., 2016; Imaizumi-Anraku et al., 2005; Lévy et al., 2004). The induced calcium oscillations are decoded by a calcium-/calmodulin-dependent kinase (CCaMK), which is the onset of a transcriptional network (Soyano \& Hayashi, 2014). Besides some common elements, like the CCaMK interacting transcription factor 
LjCYCLOPS, the activated network varies between arbuscular mycorrhizal and root nodule symbioses. For example, activation of the NIN transcription factor is essential for root nodule formation in legumes and C. glauca, whereas it is not for arbuscular mycorrhizal symbiosis (Clavijo et al., 2015; Marsh et al., 2007; Schauser, Roussis, Stiller, \& Stougaard, 1999). Conversely, arbuscular mycorrhizal symbiosis requires activation of GRAS transcription regulators such as $M t R A M 1$ in Medicago, which is not essential for root nodule formation (Gobbato et al., 2012). Despite this divergence in transcriptional responses, the common symbiotic signalling genes are conserved in angiosperm and gymnosperm species that form an arbuscular mycorrhizal symbiosis. By contrast, plants that exclusively establish an ectomycorrhizal symbiosis - e.g., Pinaceae species - have lost several of these genes (Garcia et al., 2015). This supports the idea that ectomycorrhizal symbioses are founded on different signalling cues than arbuscular mycorrhizal and root nodule endosymbioses.

\subsection{LCO Signalling}

Most comprehensive studies on symbiotic signalling have been done in the legume model systems L. japonicus and $M$. truncatula. Both species have evolved to interact with a specific rhizobial species (Mesorhizobium loti for L. japonicus and S. meliloti for M. truncatula). By using these symbiotic models, it was revealed that rhizobium LCOs are specifically recognized by a heteromeric complex of receptor-like kinases (LysM-RLKs) containing Lysine motif (LysM) domains: named LjNFR1 and LjNFR5 in L. japonicus and MtLYK3 and MtNFP in M. truncatula (Arrighi et al., 2006; Limpens et al., 2003; Madsen et al., 2003; Radutoiu et al., 2003). The LysM domain is a ubiquitous molecular structure of $42-48$ amino acids with a symmetrical $\beta \alpha \alpha \beta$ folding. LysM domain-containing proteins were first described in bacteria to bind peptidoglycan (Buist, Steen, Kok, \& Kuipers, 2008). In legumes LjNFR1/MtLYK3 and LjNFR5/MtNFP harbour three LysM domains in the receptor region which are essential to recognize specific rhizobium LCOs (Broghammer et al., 2012). In addition, it was found in L. japonicus that LjNFR5 interacts also with LjSYMRK, an LRR-type receptor that commits an essential function in symbiotic signalling (Antolín-Llovera, Ried, \& Parniske, 2014). Interestingly, This symbiotic receptor kinase (SYMRK) is also essential for arbuscular mycorrhizal symbiosis, whereas both LjNFR1/MtLYK3 and LjNFR5/MtNFP only play an additive role in arbuscular mycorrhizal symbiosis (Oldroyd, 2013). Arbuscular mycorrhizal LCOs are known to trigger lateral root 
formation in $M$. truncatula, a response that is abolished in the Mtnfp knockout mutant (Maillet et al., 2011). Mtlyk3 and Ljnfr1 mutants display only a reduced level of infection when inoculated with a low dose of arbuscular mycorrhizal spores (Zhang et al., 2015). Nevertheless, transcriptome studies in $M$. truncatula revealed that MtNFP is playing a prominent role in arbuscular mycorrhizal LCO-induced transcriptional changes (Czaja et al., 2012). Two reasons may explain this discrepancy between knockout phenotype and function. Firstly, the weak arbuscular mycorrhizal symbiosis phenotype of the Ljnr1/Mtlyk3 and Ljnfr5/Mtnfp knockout mutants may be the result of gene redundancy in L. japonicus and M. truncatula. Both rhizobium LCO receptors evolved upon gene duplication events, giving rise to closely related homologues (De Mita, Streng, Bisseling, \& Geurts, 2014; Op den Camp, De Mita, et al., 2011; Op den Camp, Streng, et al., 2011; Young et al., 2011). Expression studies of these homologous genes show that they may also function in rhizobium and/or arbuscular mycorrhizal symbiosis (Rasmussen et al., 2016; Young et al., 2011). Secondly, it was found that arbuscular mycorrhizal fungi not only produce LCOs, but also short-chain chitooligosaccharides (tetra and pentameric COs) as symbiotic signals (Genre et al., 2013). Such COs trigger in part similar symbiotic responses as reported for arbuscular mycorrhizal LCOs, though lack the capacity to promote lateral root formation (Maillet et al., 2011). LCO and CO signals may be perceived by different (symbiotic) receptor complexes.

Nonlegume systems provided additional support for a function of NFR1/LYK3 and NFR5/NFP homologous genes in arbuscular mycorrhizal symbiosis. Reverse genetic studies in Parasponia andersonii and tomato (Solanum lycopersicum) revealed an essential role for putative NFR5/NFP orthologs in arbuscular mycorrhizal symbiosis (Buendia, Wang, Girardin, \& Lefebvre, 2016; Op den Camp, De Mita, et al., 2011; Op den Camp, Streng, et al., 2011). In rice (O.sativa), it was demonstrated that the putative orthologue of NFR1/LYK3 - CHITIN-ELICITOR RECEPTOR KINASE 1 (OsCERK1)- plays such role (Miyata et al., 2014; Zhang et al., 2015). In Frankia no reverse genetic studies on LysM-RKs have been published yet. However, it is tempting to speculate that in actinorhizal plant species that can be nodulated by cluster 2 Frankia species, close homologues of NFR1/LYK3 and/or NFR5/NFP play a symbiotic role in LCO perception.

The finding that COs and the chitin innate immune receptor OsCERK1 commit symbiotic functions uncovered a functional overlap between pathogenicity and symbiosis. Subsequent studies in L. japonicus and M. truncatula 
revealed four lines of supportive evidence for such dual function of LCO receptors. (1) Rhizobium LCOs transiently trigger defence-related gene expression in an LjNFR1-dependent manner (Nakagawa et al., 2011). (2) MtNFP has a function in defence against fungal and oomycete pathogens (Ben et al., 2013; Rey, Chatterjee, Buttay, Toulotte, \& Schornack, 2015; Rey et al., 2013). (3) Ectopic expression of both receptors - LjNFR5LjNFR1 or MtNFP-MtLYK3 - in Nicotiana benthamiana leaves triggers a hypersensitive response (HR) (Broghammer et al., 2012; PietraszewskaBogiel et al., 2013). (4) Ectopic expression of MtNFP in M. truncatula triggers a premature cell death in nodules (Moling et al., 2014). This, and other studies, also made clear that LCO receptors are under tight posttranslational control in legumes, probably to prevent pathogenic responses. For example, in $M$. truncatula nodules MtNFP and MtLYK3 accumulate only in nodule cells where infection takes place, but both receptors are rapidly removed from the membrane surrounding the rhizobium infection thread (Moling et al., 2014). Furthermore, it was found that LCO receptors are located in lipid-raft-like micro-domains in the plasma membrane, which play an important role in complex formation and receptor turnover (Haney \& Long, 2010; Lefebvre et al., 2010). Taken together, these data suggest that dual functioning of LCO receptors in defence and symbiosis is a conserved feature in legumes and nonlegume species.

The biological function of the overlap of LCO receptors in symbiotic and innate immune signalling remains unclear. However, a challenging model can be postulated (Limpens et al., 2015). In this model competition between receptors occur to form multimeric complexes that differ in their functioning. Presence of LCOs (and/or short-chain COs) results in preferential formation of symbiotic receptor complexes at the expense of the formation of complexes that act in innate immunity (Fig. 3). In legumes, such innate immune receptor complex has not yet been characterized. However, studies in rice revealed that perception of chitin oligomers requires an additional LysM-domain-containing receptor, which lacks an intracellular kinase domain (Kaku et al., 2006). This chitin elicitor binding protein (OsCEBiP) binds chitin oligomers and forms a heteromeric complex with OsCERK1 to activate chitin-triggered defence responses (Hayafune et al., 2014; Shimizu et al., 2010). Such innate immune receptor complex may also have a function in symbiosis. It is known that several typical innate immune responses, such as calcium influx, production of reactive oxygen species (ROS), and focal exocytosis are associated with rhizobial and arbuscular mycorrhizal infection (Brewin, 2004). Rhizobium triggers formation of infection threads, which 


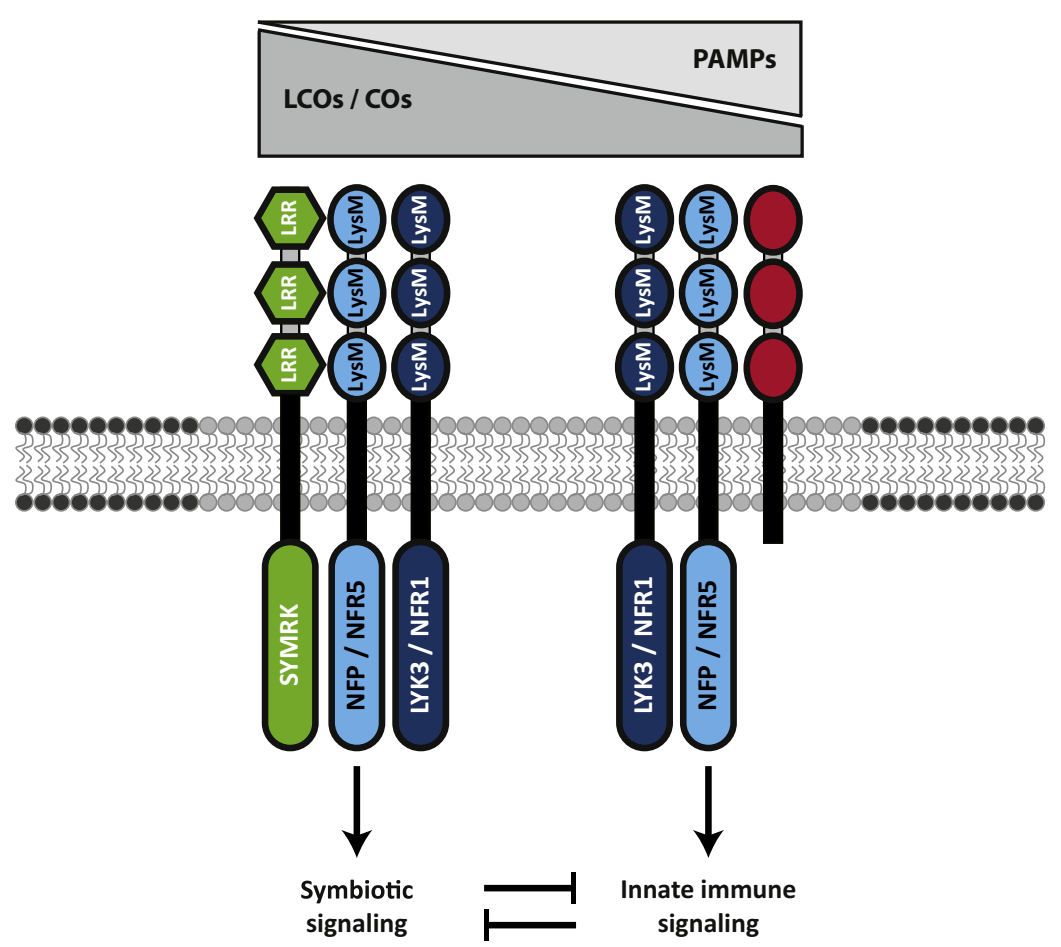

Figure 3 Hypothetical model explaining the dual functioning of LCO receptors in symbiotic and innate immune signalling as uncovered in Medicago truncatula and Lotus japonicus. Symbiotic signals and pathogen associated molecular patterns (PAMPs) are perceived by NFP/NFR5-NFR1/LYK3 receptor complexes. To commit either symbiotic or innate immune signalling a third receptor is essential. For symbiotic signalling this receptor may be symbiotic receptor kinase (SYMRK), as it interacts with NFP/NFR5. To induce innate immune responses this receptor has not been identified yet, but may have similarities to CeBIP in rice. OsCEBiP binds chitin oligomers and forms a heteromeric complex with the rice homologue of NFR1/LYK3 (OsCERK1) to activate innate immune signalling.

are tip-growing structures. ROS production is thought to facilitate the oxidative cross-linking of the infection thread matrix to allow the formation of a tube-like infection thread (Brewin, 2004). In a scenario that innate immune responses play a symbiotic role, the spatiotemporal regulation of receptor complexes becomes crucial to prevent HR.

\subsection{Bypassing LCO Signalling}

Besides LCO-mediated signalling, alternative routes occur to mediate symbiotic responses. For example, many Frankia species (clusters 1 and 3) 
do not possess the machinery to produce LCOs (Tisa, Beauchemin, Gtari, Sen, \& Wall, 2013). Furthermore, there are some legume lineages - e.g., several Aeschynomene species - that are nodulated by Bradyrhizobium strains that lack the highly conserved nod $A B C$ operon necessary for LCO synthesis (Fabre et al., 2015; Giraud et al., 2007). Nevertheless, studies in actinorhizal plant species C. glauca and Alnus glutinosa using the non-LCO producing Frankia strain Cci3i, revealed that both SYMRK and CCaMK are essential to establish a symbiotic interaction, and activation of symbiotic signalling induces calcium oscillations (Chabaud et al., 2015; Franche et al., 2011; Gherbi et al., 2008; Granqvist et al., 2015). This strongly suggests that the underlying signalling pathway to establish an endosymbiosis is highly conserved, but can be activated by different signalling inputs.

The way non-LCO-producing rhizobia and Frankia achieve activation of the common symbiosis signalling pathway may vary. One way is by producing effector-like molecules that are secreted via the type III secretion system (T3SS). This mechanism is used by several rhizobium strains (Okazaki et al., 2016), and studies in soybean revealed that such effectors can bypass NFR1-NFR5-based signalling (Okazaki, Kaneko, Sato, \& Saeki, 2013). However, additional mechanisms may also occur. For example, in case of Aeschynomene legumes the common symbiosis signalling pathway can also be activated in a T3SS-independent way (Fabre et al., 2015; Okazaki et al., 2016).

The current hypothesis is that Frankia strains of clusters 1 and 3 produce signalling molecules upon host recognition, of which the chemical nature is still poorly understood, but most probably different from LCOs. A first characterization of such signals came from studies on Frankia sp. strain CcI3i that nodulates C. glauca. The signalling molecules produced by this strain are of low molecular weight, in the range of 500-5000 Da. Moreover, rhizobium and arbuscular mycorrhizal LCOs typically accumulate in the organic fraction upon a butanol extraction, whereas, in the case of Frankia CcI3i exudates, only water fractions could induce symbiotic responses (i.e., calcium oscillation). Furthermore, a chitinase treatment on the active water fractions did not affect their signalling capacity (Chabaud et al., 2015). This makes it highly unlikely that this strain produces LCOtype symbiotic signal molecules.

Studies with other Frankia strains revealed that, at least within a taxonomic cluster, the symbiotic signals are to a certain level conserved. For example, A. glutinosa and C. glauca are nodulated by two different Frankia strains of the same cluster 1. Despite this strain specificity, Frankia sp. strain AC14a 
that nodulates $A$. glutinosa also induces calcium oscillation responses in C. glauca. By contrast, the more distant BCU110501 strain of cluster 3 was unable to induce such responses (Chabaud et al., 2015). This suggests that the symbiotic signals produced by Frankia species are partially conserved within a taxonomic cluster, but may differ in a broader phylogenetic context.

\section{REPRESSING IMMUNITY}

Although innate immune responses may be an integral part of the symbiotic infection process, it is essential that severe immune responses are avoided. Immune responses are controlled by two antagonistic hormones jasmonic acid and salicylic acid. The latter hormone is a major signal in resistance to biotrophic pathogens, whereas defence against necrotrophic mainly relies on jasmonic acid (Pieterse, Van der Does, Zamioudis, Leon-Reyes, \& Van Wees, 2012). Both hormones act antagonistically, such that activation of jasmonic acid signalling compromises salicylic acid-dependent innate immune responses, and vice versa.

Studies in legumes suggest that repression of innate immunity is in part controlled by LCO signalling. In alfalfa ( $M$. sativa) evidence was found that LCO signalling suppresses salicylic acid-dependent responses. LCOdeficient or incompatible rhizobia induce accumulation of salicylic acid, whereas compatible strains trigger a decrease of this defence hormone (Martinez-Abarca et al., 1998). Similarly, studies in pea (Pisum sativum) showed that endomycorrhizal fungi only trigger a transient increase in salicylic acid levels, which is repressed during prolonged colonization. In contrast, in a symbiosis deficient ccamk knockout mutant salicylic acid levels remain high upon inoculation with endomycorrhizal fungi, suggesting that this suppression is based on activation of the symbiosis signalling network (Blilou, Ocampo, Garcia-Garrido, \& García-Garrido, 1999). Interestingly, defence responses in nonlegumes (Zea mays, Setaria viridis), and even in non-arbuscular mycorrhizal plants ( $A$. thaliana) seem to be downregulated upon LCO perception; however, it is currently unclear how this downregulation is linked to JA and SA signalling (Liang et al., 2013; Tanaka et al., 2015).

The Jasmonic acid - salicylic acid balance is in part controlled by DELLA GRAS-type transcriptional regulators (Navarro et al., 2008). DELLAs promote jasmonic acid signalling by binding JAZ (Jasmonate zim-domain) repressor proteins (Hou, Lee, Xia, Yan, \& Yu, 2010). JAZ 
proteins repress jasmonic acid signalling upon binding with the MYC2 transcriptional activator (Boter, Ru1, \& Abdeen, 2004; Hou et al., 2010). As MYC2 activity promotes DELLA accumulation, this results in a feedforward loop in jasmonic acid signalling (Wild et al., 2012; Yang et al., 2012). Several experiments indicate that endomycorrhizal fungi and rhizobium exploit this pathway, thereby indirectly reducing salicylic acid responses. Della knockout mutants in $M$. truncatula and rice are impaired in nodulation and/or arbuscule formation (Floss, Levy, Lévesque-Tremblay, Pumplin, \& Harrison, 2013; Fonouni-Farde et al., 2016; Pimprikar et al., 2016; Yu et al., 2014). These phenotypes can be mimicked by application of gibberellins, whereas ectopic expression of a dominant active DELLA allele (MtDELLA1418) promotes symbiotic responses (Floss et al., 2013; Jin et al., 2016; Pimprikar et al., 2016). Interestingly, the dominant active allele can also complement the cyclops symbiotic signalling mutant (Floss et al., 2013). This is likely due to the fact that in $M$. truncatula the DELLA1 protein was found to be able to form a complex with CYCLOPS and CCaMK, together activating the RAM1 GRAS-type transcriptional regulator (Pimprikar et al., 2016). Taken together this suggests that MtDELLA1, by interacting with JAZ proteins, plays an important role in the LCO-signalling network and the promotion of endomycorrhizal symbiosis through the modulation of jasmonic acid-salicylic acid balance.

Besides LCO triggered repression of immunity, plant immunity can also be manipulated by microbe secreted effector proteins. Studies in arbuscular mycorrhiza and ectomycorrhiza uncovered several small secreted effector proteins that are produced by the arbuscular mycorrhizal fungus $R$. irregularis and the ectomycorrhizal fungus L. bicolor (Lin et al., 2014; Martin et al., 2008; Tisserant et al., 2013). The mode of action of two such effector proteins has been characterized.

The $R$. irregularis effector protein RiSP7 is secreted into $M$. truncatula root cells, where it localizes in the nucleus and interacts with a defence controlling ethylene-responsive transcription factor (MtERF19) (Kloppholz, Kuhn, \& Requena, 2011). In $M$. truncatula roots this gene is highly expressed upon pathogenic interaction, but only transiently during arbuscular mycorrhizal colonization. Ectopic expression of RiSP7 in $M$. truncatula roots positively affects mycorrhizal colonization, while reducing defence responses. Intriguingly, RiSP7 has some similarity to the secreted NodO protein of Rhizobium leguminosarum, which enhances LCO signalling in the host plant. However, localization studies suggest that NodO localizes in the plant membrane, 
rather than acting as a nuclear effector (Economou, Hamilton, Johnston, \& Downie, 1990; Sutton, Lea, \& Downie, 1994).

The ectomycorrhizal fungus L. bicolor expresses the LbMiSSP7 gene encoding a secreted effector protein in response to plant exuded flavonoids (Plett \& Martin, 2012). In black cottonwood poplar (Populus trichocarpa) it was shown that LbMiSSP7 is secreted in root cells where it localizes in the nucleus. There it stabilizes a JAZ protein (PtJAZ6) by direct interaction (Plett et al., 2014). As outlined above, JAZ proteins are repressors of jasmonic acid-triggered immunity. Generally, JAZ proteins are degraded upon interaction with the F-box protein COI1 (coronatine-insensitive 1). This degradation is triggered by jasmonic acid signalling. LbMiSSP7 interaction to PtJAZ6 affects formation of the JAZ-COI1 complex. This prevents the jasmonic acid-dependent degradation of JAZ, resulting in reduced plant immune responses. Given that jasmonic acid is a negative regulator of ectomycorrhizal symbiosis, counteracting this plant innate immune response promotes the plant-fungus interaction.

\section{PERSPECTIVES IN SYMBIOTIC SIGNALLING}

Central questions for future research will be on specificity of symbiotic signalling. How can a single symbiotic network that is conserved in most land plants trigger distinct root phenotypes? Since the symbiotic signalling network is basically conserved in most plant species the differences in the readout may be determined by yet unknown factors, such as the hormonal balance and/or the nutrient status of the root. For example, recently it was shown that $M$. truncatula lateral roots have an increased sensitivity to rhizobium LCOs compared with the main root. This indicates that susceptibility of a plant root varies, depending on the developmental and/or nutrient status (Sun et al., 2015).

Additional questions concerning specificity can also be addressed concerning the plant exuded flavonoids that act as attractants for symbiotic microbes. As shown for naringenin, these compounds are perceived by a diverging range of symbionts. Most probably this range extends to other soil borne microbes, most of which will not be symbiotic. Therefore, perhaps exuded flavonoids do not act as specific signals, but rather are more generic signals to which any root microbe can respond. For example, it was reported that exuded flavonoids may play a role also in phosphate and iron acquisition (Cesco, Neumann, Tomasi, Pinton, \& Weisskopf, 2010). In addition, the 
finding that flavonoids - similar to strigolactones - have a dual function, not only act as an attractant, but also function as endogenous plant signal interfering with auxin homoeostasis, provides novel leads in symbiosis research.

Extending the range of model systems that are amenable for molecular genetic studies provided novel insights into symbiotic signalling. Establishment of new protocols for culturing Frankia and arbuscular mycorrhizal fungi, host-induced gene silencing to trigger fungal gene expression, transformation of the ectomycorrhizal fungus L. bicolor, the actinorhizal plants Datsica, Casuarina, and the nonlegume rhizobia host Parasponia, in combination with microbial genome sequencing, has opened new avenues. Although unravelling symbiotic signalling in these systems is still in its infancy, findings that have been achieved since the turn of the century are already groundbreaking. As mentioned above, it was demonstrated that especially in the endosymbioses (Frankia, rhizobium and arbuscular mycorrhiza) commonalities occur in symbiotic signalling (Gherbi et al., 2008; Op den Camp, De Mita, et al., 2011; Op den Camp, Streng, et al., 2011). One such commonality is that symbionts recognize plant-secreted flavonoids and strigolactones. Another common theme is the use of LCO or CO signals of microbial origin of which biosynthesis is activated upon recognition of plant exuded molecules like flavonoids and/or strigolactones. LCOs/ COs activate a conserved symbiotic network in plants that controls the diverse signalling output of the different symbiotic interactions (Parniske, 2008). Furthermore, it became apparent that LCO-induced signalling can be bypassed. Especially in Frankia this appears to be a common strategy. Nevertheless, first studies indicate that LCO-independent signalling relies on the same symbiotic signalling network as identified in LCO-dependent systems. Uncovering the nature of the non-LCO signal molecules in Frankia and rhizobia will add a new building brick in the symbiotic signalling network.

Commonly new insights in the molecular aspects of root symbiosis are mainly generated by studying legume models M. truncatula and L. japonicus. With new model species in place in combination with next generation sequence technologies, this field will be revolutionized in the years to come.

\section{ACKNOWLEDGEMENTS}

R.Geurts is supported by NWO-VICI 865.13 .001 and W.Kohlen by NWO-VENI 863.15.010. 


\section{REFERENCES}

Abdel-Lateif, K., Vaissayre, V., Gherbi, H., Verries, C., Meudec, E., PerrineWalker, F., ... Hocher, V. (2013). Silencing of the chalcone synthase gene in Casuarina glauca highlights the important role of flavonoids during nodulation. The New Phytologist, 199, 1012-1021. http://dx.doi.org/10.1111/nph.12326.

Akiyama, K., Matsuzaki, K., \& Hayashi, H. (June, 2005). Plant sesquiterpenes induce hyphal branching in arbuscular mycorrhizal fungi. Nature, 435, 824-827. http://dx.doi.org/ 10.1038/nature03608.

Akiyama, K., Ogasawara, S., Ito, S., \& Hayashi, H. (2010). Structural requirements of strigolactones for hyphal branching in AM fungi. Plant and Cell Physiology, 51(7), 1104-1117. http://dx.doi.org/10.1093/pcp/pcq058.

Al-Babili, S., \& Bouwmeester, H. J. (2015). Strigolactones, a novel carotenoid-derived plant hormone. Annual Review of Plant Biology, 66(1), 161-186. http://dx.doi.org/10.1146/ annurev-arplant-043014-114759.

Alder, A., Jamil, M., Marzorati, M., Bruno, M., Vermathen, M., Bigler, P., ... Al-Babili, S. (2012). The path from -carotene to carlactone, a strigolactone-like plant hormone. Science, 335(6074), 1348-1351. http://dx.doi.org/10.1126/science.1218094.

Antolín-Llovera, M., Ried, M. K., \& Parniske, M. (2014). Cleavage of the SYMBIOSIS RECEPTOR- LIKE KINASE ectodomain promotes complex formation with Nod factor receptor 5. Current Biology, 24, 422-427.

Arrighi, J. F., Barre, A., Ben Amor, B., Bersoult, A., Soriano, L. C., Mirabella, R.,... Gough, C. (2006). The Medicago truncatula lysine motif-receptor-like kinase gene family includes NFP and new nodule-expressed genes. Plant Physiology, 142(1), 265-279. http://dx.doi.org/10.1104/pp.106.084657.

Auguy, F., Abdel-Lateif, K., Doumas, P., Badin, P., Guerin, V., Bogusz, D., \& Hocher, V. (2011). Activation of the isoflavonoid pathway in actinorhizal symbioses. Functional Plant Biology, 38(8-9), 690-696. http://dx.doi.org/10.1071/FP11014.

Balestrini, R., \& Bonfante, P. (2005). The interface compartment in arbuscular mycorrhizae: a special type of plant cell wall? Plant Biosystems - An International Journal Dealing with All Aspects of Plant Biology, 139(1), 8-15. http://dx.doi.org/10.1080/11263500500056799.

Balestrini, R., \& Bonfante, P. (June, 2014). Cell wall remodeling in mycorrhizal symbiosis: a way towards biotrophism. Frontiers in Plant Science, 5, 237. http://dx.doi.org/10.3389/ fpls.2014.00237.

Beauchemin, N. J., Furnholm, T., Lavenus, J., Svistoonoff, S., Doumas, P., Bogusz, D., ... Tisa, L. S. (2012). Casuarina root exudates alter the physiology, surface properties, and plant infectivity of Frankia sp. strain CcI3. Applied and Environmental Microbiology, 78(2), 575-580. http://dx.doi.org/10.1128/AEM.06183-11.

Bécard, G., Douds, D. D., \& Pfeffer, P. E. (1992). Extensive in vitro hyphal growth of vesicular-arbuscular mycorrhizal fungi in the presence of $\mathrm{CO}_{2}$ and flavonols extensive in vitro hyphal growth of vesicular-arbuscular mycorrhizal fungi in the presence of $\mathrm{CO}_{2}$ and flavonols. Applied and Environmental Microbiology, 58(3), 821-825.

Bécard, G., Taylor, L. P., Douds, D. D., Pfeffer, P. E., \& Doner, L. W. (1995). Flavonoids are not necessary plant signal compounds in arbuscular mycorrhizal symbioses. Molecular Plant-Microbe Interactions. http://dx.doi.org/10.1094/MPMI-8-0252.

Behm, J. E., Geurts, R., \& Kiers, E. T. (2014). Parasponia: a novel system for studying mutualism stability. Trends in Plant Science, 19(12), 757-763. http://dx.doi.org/ 10.1016/j.tplants.2014.08.007.

Ben, C., Toueni, M., Montanari, S., Tardin, M.-C., Fervel, M., Negahi, A., ... Gentzbittel, L. (2013). Natural diversity in the model legume Medicago truncatula allows identifying distinct genetic mechanisms conferring partial resistance to Verticillium wilt. Journal of Experimental Botany, 64, 317-332. http://dx.doi.org/10.1093/jxb/ers337. 
Besserer, A., Bécard, G., Jauneau, A., Roux, C., \& Séjalon-Delmas, N. (2008). GR24, a synthetic analog of strigolactones, stimulates the mitosis and growth of the arbuscular mycorrhizal fungus Gigaspora rosea by boosting its energy metabolism. Plant Physiology, 148(1), 402-413. http://dx.doi.org/10.1104/pp.108.121400.

Besserer, A., Puech-Pagès, V., Kiefer, P., Gomez-Roldan, V., Jauneau, A., Roy, S., ... Séjalon-Delmas, N. (2006). Strigolactones stimulate arbuscular mycorrhizal fungi by activating mitochondria. PLoS Biology, 4(7), 1239-1247. http://dx.doi.org/ 10.1371/journal.pbio.0040226.

Blilou, I., Ocampo, J. A., Garcia-Garrido, M., \& García-Garrido, J. M. (1999). Resistance of pea roots to endomycorrhizal fungus or Rhizobium correlates with enhanced levels of endogenous salicylic acid. Journal of Experimental Botany, 50(340), 1663-1668. http:// dx.doi.org/10.1093/jxb/50.340.1663.

Boter, M., Ru1, O., \& Abdeen, A. (2004). Conserved MYC transcription factors play a key role in jasmonate signaling both in tomato and Arabidopsis. Genes and Development, 2, 1577-1591. http://dx.doi.org/10.1101/gad.297704.tion.

Brewer, P. B., Koltai, H., \& Beveridge, C. A. (2013). Diverse roles of strigolactones in plant development. Molecular Plant, 6(1), 18-28. http://dx.doi.org/10.1093/mp/sss130.

Brewin, N. J. (2004). Plant cell wall remodelling in the Rhizobium-legume symbiosis. Critical Reviews in Plant Sciences, 23(4), 293-316. http://dx.doi.org/10.1080/ 07352680490480734.

Broghammer, A., Krusell, L., Blaise, M., Sauer, J., Sullivan, J. T., Maolanon, N., ... Stougaard, J. (2012). Legume receptors perceive the rhizobial lipochitin oligosaccharide signal molecules by direct binding. Proceedings of the National Academy of Sciences of the United States of America, 109(34), 13859-13864. http://dx.doi.org/ 10.1073/pnas.1205171109.

Brown, D. E., Rashotte, A. M., Murphy, A. S., Normanly, J., Tague, B. W., Peer, W. A., ... Muday, G. K. (2001). Flavonoids act as negative regulators of auxin transport in vivo in arabidopsis. Plant Physiology, 126(2), 524-535. http://dx.doi.org/ 10.1104/pp.126.2.524.

Buendia, L., Wang, T., Girardin, A., \& Lefebvre, B. (2016). The LysM receptor-like kinase SILYK10 regulates the arbuscular mycorrhizal symbiosis in tomato. The New Phytologist, 210(1), 184-195. http://dx.doi.org/10.1111/nph.13753.

Buist, G., Steen, A., Kok, J., \& Kuipers, O. P. (April 2008). LysM, a widely distributed protein motif for binding to (peptido)glycans. Molecular Microbiology, 68, 838-847. http://dx.doi.org/10.1111/j.1365-2958.2008.06211.x.

Capoen, W., Sun, J., Wysham, D., Otegui, M. S., Venkateshwaran, M., Hirsch, S., ... Oldroyd, G. E. D. (2011). Nuclear membranes control symbiotic calcium signaling of legumes. Proceedings of the National Academy of Sciences of the United States of America, 108(34), 14348-14353. http://dx.doi.org/10.1073/pnas.1107912108.

Catoira, R., Galera, C., de Billy, F., Penmetsa, R. V., Journet, E. P., Maillet, F., ... Denarie, J. (2000). Four genes of Medicago truncatula controlling components of a nod factor transduction pathway. The Plant Cell, 12(9), 1647-1666. Retrieved from http://www.ncbi.nlm.nih.gov/pubmed/11006338.

Cesco, S., Neumann, G., Tomasi, N., Pinton, R., \& Weisskopf, L. (2010). Release of plant-borne flavonoids into the rhizosphere and their role in plant nutrition. Plant Soil, 329, 1-25. http://dx.doi.org/10.1007/s11104-009-0266-9.

Chabaud, M., Gherbi, H., Pirolles, E., Vaissayre, V., Moukouanga, D., Franche, C., ... Svistoonoff, S. (2015). Rapid report chitinase-resistant hydrophilic symbiotic factors secreted by Frankia activate both $\mathrm{Ca}^{2+}$ spiking and NIN gene expression in the actinorhizal plant Casuarina glauca. The New Phytologist. http://dx.doi.org/ 10.1111/nph.13732. 
Charpentier, M., Sun, J., Martins, T. V., Radhakrishnan, G. V., Findlay, K., Soumpourou, E., ... Oldroyd, G. E. D. (2016). Nuclear-localized cyclic nucleotidegated channels mediate symbiotic calcium oscillations. Science, 352(6289), 1102-1105. http://dx.doi.org/10.1126/science.aae0109.

Chen, X.-C., Feng, J., Hou, B.-H., Li, F.-Q., Li, Q., \& Hong, G.-F. (2005). Modulating DNA bending affects NodD-mediated transcriptional control in Rhizobium leguminosarum. Nucleic Acids Research, 33(8), 2540-2548. http://dx.doi.org/10.1093/ nar/gki537.

Clavijo, F., Diedhiou, I., Vaissayre, V., Brottier, L., Acolatse, J., Moukouanga, D., ... Svistoonoff, S. (2015). The Casuarina NIN gene is transcriptionally activated throughout Frankia root infection as well as in response to bacterial diffusible signals. The New Phytologist, 208, 887-903. http://dx.doi.org/10.1111/nph.13506.

Coleman-Derr, D., \& Tringe, S. G. (June 2014). Building the crops of tomorrow: advantages of symbiont-based approaches to improving abiotic stress tolerance. Frontiers in Microbiology, 5, 1-6. http://dx.doi.org/10.3389/fmicb.2014.00283.

Czaja, L. F., Hogekamp, C., Lamm, P., Maillet, F., Martinez, E.a., Samain, E., ... Hohnjec, N. (2012). Transcriptional responses toward diffusible signals from symbiotic microbes reveal MtNFP- and MtDMI3-dependent reprogramming of host gene expression by arbuscular mycorrhizal fungal Lipochitooligosaccharides. Plant Physiology, 159(4), 1671-1685. http://dx.doi.org/10.1104/pp.112.195990.

De Cuyper, C., Fromentin, J., Yocgo, R. E., De Keyser, A., Guillotin, B., Kunert, K., ... Goormachtig, S. (2014). From lateral root density to nodule number, the strigolactone analogue GR24 shapes the root architecture of Medicago truncatula. Journal of Experimental Botany, 66(1), 137-146. http://dx.doi.org/10.1093/jxb/eru404.

De Mita, S., Streng, A., Bisseling, T., \& Geurts, R. (2014). Evolution of a symbiotic receptor through gene duplications in the legume-rhizobium mutualism. The New Phytologist, 201(3), 961-972. http://dx.doi.org/10.1111/nph.12549.

Deinum, E. E., Geurts, R., Bisseling, T., \& Mulder, B. M. (May 2012). Modeling a cortical auxin maximum for nodulation: different signatures of potential strategies. Frontiers in Plant Science, 3, 1-19. http://dx.doi.org/10.3389/fpls.2012.00096.

Dor, E., Joel, D. M., Kapulnik, Y., Koltai, H., \& Hershenhorn, J. (2011). The synthetic strigolactone GR24 influences the growth pattern of phytopathogenic fungi. Planta, 234(2), 419-427. http://dx.doi.org/10.1007/s00425-011-1452-6.

Economou, A., Hamilton, W. D., Johnston, A. W., \& Downie, J. A. (1990). The rhizobium nodulation gene nodO encodes a $\mathrm{Ca} 2(+)$-binding protein that is exported without $\mathrm{N}$-terminal cleavage and is homologous to haemolysin and related proteins. The EMBO Journal, 9(2), 349-354. Retrieved from http://www.ncbi.nlm.nih.gov/ pubmed/2303029.

Ellouze, W., Hamel, C., Cruz, A. F., Ishii, T., Gan, Y., Bouzid, S., \& St-Arnaud, M. (2012). Phytochemicals and spore germination: at the root of AMF host preference? Applied Soil Ecology, 60, 98-104. http://dx.doi.org/10.1016/j.apsoil.2012.02.004.

Fabre, S., Gully, D., Poitout, A., Patrel, D., Arrighi, J.-F., Giraud, E., ... Cartieaux, F. (December 2015). The Nod factor-independent nodulation in Aeschynomene evenia required the common plant-microbe symbiotic "toolkit". Plant Physiology, 169, 2654-2664. http://dx.doi.org/10.1104/pp.15.01134.

Falcone Ferreyra, M. L., Rius, S. P., \& Casati, P. (September 2012). Flavonoids: biosynthesis, biological functions, and biotechnological applications. Frontiers in Plant Science, 3, 1-15. http://dx.doi.org/10.3389/fpls.2012.00222.

Ferrer, J. L., Austin, M. B., Stewart, C., \& Noel, J. P. (2008). Structure and function of enzymes involved in the biosynthesis of phenylpropanoids. Plant Physiology and Biochemistry, 46(3), 356-370. http://dx.doi.org/10.1016/j.plaphy.2007.12.009. 
Floss, D. S., Levy, J. G., Lévesque-Tremblay, V., Pumplin, N., \& Harrison, M. J. (2013). DELLA proteins regulate arbuscule formation in arbuscular mycorrhizal symbiosis. Proceedings of the National Academy of Sciences of the United States of America, 110(51), E5025-E5034. http://dx.doi.org/10.1073/pnas.1308973110.

Fonouni-Farde, C., Tan, S., Baudin, M., Brault, M., Wen, J., Mysore, K. S., ... Diet, A. (2016). DELLA-mediated gibberellin signalling regulates Nod factor signalling and rhizobial infection. Nature Communications, 7, 12636. http://dx.doi.org/10.1038/ ncomms12636.

Foo, E., Yoneyama, K., Hugill, C. J., Quittenden, L. J., \& Reid, J. B. (2013). Strigolactones and the regulation of pea symbioses in response to nitrate and phosphate deficiency. Molecular Plant, 6(1), 76-87. http://dx.doi.org/10.1093/mp/sss115.

Franche, C., Gherbi, H., Benabdoun, M., Svistoonoff, S., Hocher, V., \& Bogusz, D. (2011). New insights in the molecular events underlying actinorhizal nodulation in the tropical tree Casuarina glauca. BMC Proceedings, 5(Suppl. 7), O33. http://dx.doi.org/10.1186/ 1753-6561-5-S7-O33.

Garcia, K., Delaux, P.-M., Cope, K. R., \& Ane, J.-M. (2015). Molecular signals required for the establishment and maintenance of ectomycorrhizal symbioses. The New Phytologist, 208, 79-87. http://dx.doi.org/10.1080/15411790701409895.

Garg, N., \& Singla, P. (2016). Stimulation of nitrogen fixation and trehalose biosynthesis by naringenin (Nar) and arbuscular mycorrhiza (AM) in chickpea under salinity stress. Plant Growth Regulation, 1-18. http://dx.doi.org/10.1007/s10725-016-0146-2.

Gea, L., Normand, L., Vian, B., \& Gay, G. (December 1994). Structural aspects of ectomycorrhiza of Pinus Pinaster (Ait) Sol formed by an Iaa overproducer mutant of Hebeloma cylindrosporum Romagnesi. The New Phytologist, 128(4), 659-670. http:// dx.doi.org/10.1111/j.1469-8137.1994.tb04030.x.

Genre, A., Chabaud, M., Balzergue, C., Puech-Pagès, V., Novero, M., Rey, T.,... Barker, D. G. (2013). Short-chain chitin oligomers from arbuscular mycorrhizal fungi trigger nuclear $\mathrm{Ca}^{2+}$ spiking in Medicago truncatula roots and their production is enhanced by strigolactone. The New Phytologist, 198, 190-202. http:// dx.doi.org/10.1111/nph.12146.

Geurts, R., Lillo, A., \& Bisseling, T. (2012). Exploiting an ancient signalling machinery to enjoy a nitrogen fixing symbiosis. Current Opinion in Plant Biology, 15(4), 438-443. http://dx.doi.org/10.1016/j.pbi.2012.04.004.

Geurts, R., Xiao, T. T., \& Reinhold-Hurek, B. (2016). What does it take to evolve a nitrogen-fixing endosymbiosis? Trends in Plant Science, 21(3), 199-208. http:// dx.doi.org/10.1016/j.tplants.2016.01.012.

Gherbi, H., Markmann, K., Svistoonoff, S., Estevan, J., Autran, D., Giczey, G., ... Bogusz, D. (2008). SymRK defines a common genetic basis for plant root endosymbioses with arbuscular mycorrhiza fungi, rhizobia. Proceedings of the National Academy of Sciences of the United States of America, 105(12), 4928-4932. http://dx.doi.org/ 10.1073/pnas.0710618105.

Giraud, E., Moulin, L., Vallenet, D., Barbe, V., Cytryn, E., Avarre, J.-C., ... Sadowsky, M. (2007). Legumes symbioses: absence of Nod genes in photosynthetic bradyrhizobia. Science, 316(5829), 1307-1312. http://dx.doi.org/10.1126/science.1139548.

Gobbato, E., Marsh, J. F., Vernié, T., Wang, E., Maillet, F., Kim, J., ... Oldroyd, G. E. D. (2012). A GRAS-type transcription factor with a specific function in mycorrhizal signaling. Current Biology, 22(23), 2236-2241. http://dx.doi.org/10.1016/ j.cub.2012.09.044.

Gomez-Roldan, V., Fermas, S., Brewer, P. B., Puech-Pagès, V., Dun, E. A., Pillot, J.-P.,... Rochange, S. F. (2008). Strigolactone inhibition of shoot branching. Nature, 455(7210), 189-194. http://dx.doi.org/10.1038/nature07271. 
Granqvist, E., Sun, J., Op Den Camp, R., Pujic, P., Hill, L., Normand, P., ... Oldroyd, G. E. D. (2015). Bacterial-induced calcium oscillations are common to nitrogen-fixing associations of nodulating legumes and nonlegumes. The New Phytologist, 207(3), 551-558. http://dx.doi.org/10.1111/nph.13464.

Gtari, M., Tisa, L. S., \& Normand, P. (2013). Diversity of Frankia strains, actinobacterial symbionts of actinorhizal plants. In R. Aroca (Ed.), Symbiotic endophytes (Vol. 37, pp. 123-148). Berlin, Heidelberg: Springer. http://dx.doi.org/10.1007/ 978-3-642-39317-4.

Gutjahr, C., Gobbato, E., Choi, J., Riemann, M., Johnston, M. G., Summers, W.,... Paszkowski, U. (2015). Rice perception of symbiotic arbuscular mycorrhizal fungi requires the karrikin receptor complex. Science, 350(6267), 1521-1524. http://dx.doi.org/10.1126/science.aac9715.

Hamiaux, C., Drummond, R. S. M. S. M., Janssen, B. J. J., Ledger, S. E. E., Cooney, J. M. M., Newcomb, R. D. D., \& Snowden, K. C. C. (2012). DAD2 is an $\alpha / \beta$ hydrolase likely to be involved in the perception of the plant branching hormone, strigolactone. Current Biology, 22(21), 2032-2036. http://dx.doi.org/10.1016/ j.cub.2012.08.007.

Haney, C. H., \& Long, S. R. (2010). Plant flotillins are required for infection by nitrogenfixing bacteria. Proceedings of the National Academy of Sciences of the United States of America, 107(1), 478-483. http://dx.doi.org/10.1073/pnas.0910081107.

Hartwig, U. A., Joseph, C. M., \& Phillips, D. A. (1991). Flavonoids released naturally from alfalfa seeds enhance growth rate of Rhizobium meliloti. Plant Physiology, 95(3), 797-803. http://dx.doi.org/10.1104/pp.95.3.797.

Hayafune, M., Berisio, R., Marchetti, R., Silipo, A., Kayama, M., Desaki, Y., ... Shibuya, N. (2014). Chitin-induced activation of immune signaling by the rice receptor CEBiP relies on a unique sandwich-type dimerization. Proceedings of the National Academy of Sciences of the United States of America, 111, E404-E413. http://dx.doi.org/10.1073/ pnas. 1312099111.

Heckmann, A. B., Lombardo, F., Miwa, H., Perry, J. A., Bunnewell, S., Parniske, M., ... Downie, J. A. (2006). Lotus japonicus nodulation requires two GRAS domain regulators, one of which is functionally conserved in a non-legume. Plant Physiology, 142(4), 1739-1750. http://dx.doi.org/10.1104/pp.106.089508.

Hirsch, A. M., Bhuvaneswari, T. V., Torrey, J. G., \& Bisseling, T. (1989). Early nodulin genes are induced in alfalfa root outgrowths elicited by auxin transport inhibitors. Proceedings of the National Academy of Sciences of the United States of America, 86(4), 1244-1248. http://dx.doi.org/10.1073/pnas.86.4.1244.

Honma, M. A., Asomaning, M., \& Ausubel, F. M. (1990). Rhizobium meliloti nodD genes mediate host-specific activation of nodABC. Journal of Bacteriology, 172(2), 901-911. Retrieved from http://www.ncbi.nlm.nih.gov/pubmed/2298703.

Hou, X., Lee, L. Y. C., Xia, K., Yan, Y., \& Yu, H. (2010). DELLAs modulate jasmonate signaling via competitive binding to JAZs. Developmental Cell, 19(6), 884-894. http:// dx.doi.org/10.1016/j.devcel.2010.10.024.

Imaizumi-Anraku, H., Takeda, N., Charpentier, M., Perry, J., Miwa, H., Umehara, Y., ... Hayashi, M. (2005). Plastid proteins crucial for symbiotic fungal and bacterial entry into plant roots. Nature, 433(7025), 527-531. http://dx.doi.org/ 10.1038/nature03237.

Jin, Y., Liu, H., Luo, D., Yu, N., Dong, W., Wang, C., ... Wang, E. (2016). DELLA proteins are common components of symbiotic rhizobial and mycorrhizal signalling pathways. Nature Communications, 7, 12433. http://dx.doi.org/10.1038/ncomms12433.

Jones, D. L., Nguyen, C., \& Finlay, R. D. (2009). Carbon flow in the rhizosphere: carbon trading at the soil-root interface. Plant and Soil, 321(1-2), 5-33. http://dx.doi.org/ 10.1007/s11104-009-9925-0. 
Kaku, H., Nishizawa, Y., Ishii-Minami, N., Akimoto-Tomiyama, C., Dohmae, N., Takio, K., ... Shibuya, N. (2006). Plant cells recognize chitin fragments for defence signaling through a plasma membrane receptor. Proceedings of the National Academy of Sciences of the United States of America, 103, 11086-11091. http://dx.doi.org/10.1073/ pnas.0508882103.

Kikuchi, K., Matsushita, N., Suzuki, K., \& Hogetsu, T. (2007). Flavonoids induce germination of basidiospores of the ectomycorrhizal fungus Suillus bovinus. Mycorrhiza, 17(7), 563-570. http://dx.doi.org/10.1007/s00572-007-0131-8.

Kloppholz, S., Kuhn, H., \& Requena, N. (2011). A secreted fungal effector of Glomus intraradices promotes symbiotic biotrophy. Current Biology, 21(14), 1204-1209. http:// dx.doi.org/10.1016/j.cub.2011.06.044.

Kohlen, W., Charnikhova, T., Lammers, M., Pollina, T., Tóth, P., Haider, I., ... LópezRáez, J. A. (2012). The tomato carotenoid cleavage dioxygenase8 (SlCCD8) regulates rhizosphere signaling, plant architecture and affects reproductive development through strigolactone biosynthesis. The New Phytologist, 196(2), 535-547. http://dx.doi.org/ 10.1111/j.1469-8137.2012.04265.x.

Kohler, A., Kuo, A., Nagy, L. G., Morin, E., Barry, K. W., Buscot, F., .. Martin, F. (2015). Convergent losses of decay mechanisms and rapid turnover of symbiosis genes in mycorrhizal mutualists. Nature Genetics, 47(4), 410-415. http://dx.doi.org/10.1038/ ng.3223.

Kosslak, R. M., Bookland, R., Barkei, J., Paaren, H. E., \& Appelbaum, E. R. (1987). Induction of Bradyrhizobium japonicum common nod genes by isoflavones isolated from Glycine max. Proceedings of the National Academy of Sciences of the United States of America, 84(21), 7428-7432. Retrieved from http://www.ncbi.nlm.nih.gov/pubmed/ 16593884.

Kretzschmar, T., Kohlen, W., Sasse, J., Borghi, L., Schlegel, M., Bachelier, J. B.,... Martinoia, E. (2012). A petunia ABC protein controls strigolactone-dependent symbiotic signalling and branching. Nature. http:// dx.doi.org/10.1038/nature10873. Nature Publishing Group.

Lefebvre, B., Timmers, T., Mbengue, M., Moreau, S., Hervé, C., Tóth, K.,... Ott, T. (2010). A remorin protein interacts with symbiotic receptors and regulates bacterial infection. Proceedings of the National Academy of Sciences of the United States of America, 107(5), 2343-2348. http://dx.doi.org/10.1073/pnas.0913320107.

Lévy, J., Bres, C., Geurts, R., Chalhoub, B., Kulikova, O., Duc, G., .. Debellé, F. (2004). A putative $\mathrm{Ca}^{2+}$ and calmodulin-dependent protein kinase required for bacterial and fungal symbioses. Science, 303(5662), 1361-1364. http://dx.doi.org/10.1126/ science.1093038.

Liang, Y., Cao, Y., Tanaka, K., Thibivilliers, S., Wan, J., Choi, J., ... Stacey, G. (2013). Nonlegumes respond to rhizobial Nod factors by suppressing the innate immune response. Science, 341(6152), 1384-1387. http://dx.doi.org/10.1126/science.1242736.

Limpens, E., Franken, C., Smit, P., Willemse, J., Bisseling, T., \& Geurts, R. (2003). LysM domain receptor kinases regulating rhizobial Nod factor-induced infection. Science, 302(5645), 630-633. http://dx.doi.org/10.1126/science.1090074.

Limpens, E., van Zeijl, A., \& Geurts, R. (2015). Lipochitooligosaccharides modulate plant host immunity to enable endosymbioses. Annual Review of Phytopathology, 53(1), 311-334. http://dx.doi.org/10.1146/annurev-phyto-080614-120149.

Lin, K., Limpens, E., Zhang, Z., Ivanov, S., Saunders, D. G. O., Mu, D.,... Huang, S. (2014). Single nucleus genome sequencing reveals high similarity among nuclei of an endomycorrhizal fungus. PLoS Genetics, 10, e1004078. http://dx.doi.org/10.1371/ journal.pgen.1004078.

Liu, J., Novero, M., Charnikhova, T., Ferrandino, A., Schubert, A., RuyterSpira, C., ... Cardinale, F. (2013). Carotenoid cleavage dioxygenase 7 modulates plant 
growth, reproduction, senescence, and determinate nodulation in the model legume Lotus japonicus. Journal of Experimental Botany, 64(7), 1967-1981. http://dx.doi.org/ 10.1093/jxb/ert056.

Liu, W., Kohlen, W., Lillo, A., Op den Camp, R., Ivanov, S., Hartog, M., ... Geurts, R. (2011). Strigolactone biosynthesis in Medicago truncatula and rice requires the symbiotic GRAS-type transcription factors NSP1 and NSP2. The Plant Cell, 23(10), 3853-3865. http://dx.doi.org/10.1105/tpc.111.089771.

Madsen, E. B., Madsen, L. H., Radutoiu, S., Sato, S., Kaneko, T., Tabata, S., \& Sandal, N. (2003). A receptor kinase gene of the LysM type is involved in legume perception of rhizobial signals. Nature, 425, 637-640.

Maillet, F., Poinsot, V., André, O., Puech-Pagès, V., Haouy, A., Gueunier, M., ... Dénarié, J. (2011). Fungal lipochitooligosaccharide symbiotic signals in arbuscular mycorrhiza. Nature, 469(7328), 58-63. http://dx.doi.org/10.1038/ nature09622.

Marsh, J. F., Rakocevic, A., Mitra, R. M., Brocard, L., Sun, J., Eschstruth, A., ... Oldroyd, G. E. D. D. (2007). Medicago truncatula NIN is essential for rhizobial-independent nodule organogenesis induced by autoactive calcium/ calmodulin-dependent protein kinase. Plant Physiology, 144(1), 324-335. http:// dx.doi.org/10.1104/pp.106.093021.

Martin, F., Aerts, A., Ahrén, D., Brun, A., Danchin, E. G. J., Duchaussoy, F., ... Grigoriev, I. V. (2008). The genome of Laccaria bicolor provides insights into mycorrhizal symbiosis. Nature, 452(7183), 88-92. http://dx.doi.org/ 10.1038/nature06556.

Martin, F., Kohler, A., Murat, C., Veneault-Fourrey, C., David, S., \& Hibbett, D. S. (2016). Unearthing the roots of ectomycorrhizal symbioses. Nature Reviews Microbiology. http:// dx.doi.org/10.1038/nrmicro.2016.149.

Martinez-Abarca, F., Herrera-Cervera, J. A., Bueno, P., Sanjuan, J., Bisseling, T., \& Olivares, J. (1998). Involvement of salicylic acid in the establishment of the Rhizobium meliloti -alfalfa symbiosis. Molecular Plant-Microbe Interactions, 11, 153-155. http:// dx.doi.org/10.1094/MPMI.1998.11.2.153.

Mathesius, U., Schlaman, H. R., Spaink, H. P., Of Sautter, C., Rolfe, B. G., \& Djordjevic, M. A. (1998). Auxin transport inhibition precedes root nodule formation in white clover roots and is regulated by flavonoids and derivatives of chitin oligosaccharides. Plant Journal, 14(1), 23-34. http://dx.doi.org/10.1046/j.1365313X.1998.00090.x.

Mendes, R., Garbeva, P., \& Raaijmakers, J. M. (2013). The rhizosphere microbiome: significance of plant beneficial, plant pathogenic, and human pathogenic microorganisms. FEMS Microbiology Reviews, 37(5), 634-663. http://dx.doi.org/10.1111/15746976.12028.

Miyata, K., Kozaki, T., Kouzai, Y., Ozawa, K., Ishii, K., Asamizu, E., ... Nakagawa, T. (2014). Bifunctional plant receptor, OsCERK1, regulates both chitin-triggered immunity and arbuscular mycorrhizal symbiosis in rice. Plant and Cell Physiology, 55(11), 1864-1872. http://dx.doi.org/10.1093/pcp/pcu129.

Moling, S., Pietraszewska-Bogiel, A., Postma, M., Fedorova, E., Hink, M. A., Limpens, E., ... Bisseling, T. (October 2014). Nod factor receptors form heteromeric complexes and are essential for intracellular infection in medicago nodules. The Plant Cell, 26, 4188-4199. http://dx.doi.org/10.1105/tpc.114.129502.

Mulligan, J. T., \& Long, S. R. (1989). A family of activator genes regulates expression of Rhizobium meliloti nodulation genes. Genetics, 122(1), 7-18. Retrieved from http:// www.ncbi.nlm.nih.gov/pubmed/2731734.

Nakagawa, T., Kaku, H., Shimoda, Y., Sugiyama, A., Shimamura, M., Takanashi, K., ... Kouchi, H. (2011). From defence to symbiosis: limited alterations in 
the kinase domain of LysM receptor-like kinases are crucial for evolution of legumeRhizobium symbiosis. The Plant Journal, 65(2), 169-180. http://dx.doi.org/10.1111/ j.1365-313X.2010.04411.x.

Navarro, L., Bari, R., Achard, P., Lisón, P., Nemri, A., Harberd, N. P., \& Jones, J. D. G. (2008). DELLAs control plant immune responses by modulating the balance of jasmonic acid and salicylic acid signaling. Current Biology, 18, 650-655. http://dx.doi.org/ 10.1016/j.cub.2008.03.060.

Navarro-Rodenas, A., Xu, H., Kemppainen, M., Pardo, A. G., \& Zwiazek, J. J. (2015). Laccaria bicolor aquaporin LbAQP1 is required for Hartig net development in trembling aspen (Populus tremuloides). Plant, Cell and Environment, 38(11), 2475-2486. http:// dx.doi.org/10.1111/pce.12552.

Ng, J., Perrine-Walker, F., Wasson, A., \& Mathesius, U. (2015). The control of auxin transport in parasitic and symbiotic root-microbe interactions. Plants, 4(3), 606-643. http://dx.doi.org/10.3390/plants4030606.

Okazaki, S., Kaneko, T., Sato, S., \& Saeki, K. (2013). Hijacking of leguminous nodulation signaling by the rhizobial type III secretion system. Proceedings of the National Academy of Sciences of the United States of America, 110(42), 17131-17136. http://dx.doi.org/ 10.1073/pnas.1302360110.

Okazaki, S., Tittabutr, P., Teulet, A., Thouin, J., Fardoux, J., Chaintreuil, C., ... Giraud, E. (2016). Rhizobium-legume symbiosis in the absence of Nod factors: two possible scenarios with or without the T3SS. The ISME Journal, 10, 64-74. http://dx.doi.org/ 10.1038/ismej.2015.103.

Oldroyd, G. E. D. (2013). Speak, friend, and enter: signalling systems that promote beneficial symbiotic associations in plants. Nature Reviews. Microbiology, 11(4), 252-263. http:// dx.doi.org/10.1038/nrmicro2990.

Oldroyd, G. E., \& Long, S. R. (2003). Identification and characterization of nodulationsignaling pathway 2, a gene of Medicago truncatula involved in Nod factor signaling. Plant Physiology, 131(3), 1027-1032. http://dx.doi.org/10.1104/pp.102.010710.

Op den Camp, R. H. M., De Mita, S., Lillo, A., Cao, Q., Limpens, E., Bisseling, T., \& Geurts, R. (2011). A phylogenetic strategy based on a legume-specific whole genome duplication yields symbiotic cytokinin type-A response regulators. Plant Physiology, 157(December 2011), 2013-2022. http://dx.doi.org/10.1104/pp.111.187526.

Op den Camp, R. H. M., Streng, A., De Mita, S., Cao, Q., Polone, E., Liu, W.,... Geurts, R. (December 2011). LysM-type mycorrhizal receptor recruited for rhizobium symbiosis in nonlegume Parasponia. Science, 331, 909-912. http:// dx.doi.org/10.1126/science.1198181.

Pandey, A., Sharma, M., \& Pandey, G. K. (2016). Emerging roles of strigolactones in plant responses to stress and development. Frontiers in Plant Science, 7(434). http://dx.doi.org/ $10.3389 /$ fpls.2016.00434.

Parniske, M. (2008). Arbuscular mycorrhiza: the mother of plant root endosymbioses. Nature Reviews Microbiology, 6, 763-775. http://dx.doi.org/10.1038/nrmicro1987.

Pawlowski, K., \& Demchenko, K. N. (2012). The diversity of actinorhizal symbiosis. Protoplasma, 249(4), 967-979. http://dx.doi.org/10.1007/s00709-012-0388-4.

Peláez-Vico, M. A., Bernabéu-Roda, L., Kohlen, W., Soto, M. J., \& López-Ráez, J. A. (2016). Strigolactones in the rhizobium-legume symbiosis: stimulatory effect on bacterial surface motility and down-regulation of their levels in nodulated plants. Plant Science, 245, 119-127. http://dx.doi.org/10.1016/j.plantsci.2016.01.012.

Persson, T., Battenberg, K., Demina, I. V., Vigil-Stenman, T., Vanden Heuvel, B., Pujic, P., ... Berry, A. M. (2015). Candidatus Frankia Datiscae Dg1, the actinobacterial microsymbiont of Datisca glomerata, expresses the canonical nod genes nodABC in symbiosis with its host plant. PLoS One, 10(5), e0127630. http://dx.doi.org/10.1371/ journal.pone.0127630. 
Peters, N. K., \& Long, S. R. (1988). Alfalfa root exudates and compounds which promote or Inhibit induction of Rhizobium meliloti nodulation genes. Plant Physiology, 88(2), 396-400. Retrieved from http://www.ncbi.nlm.nih.gov/pubmed/16666315.

Pieterse, C. M. J., Van der Does, D., Zamioudis, C., Leon-Reyes, A., \& Van Wees, S. C. M. (2012). Hormonal modulation of plant immunity. Annual Review of Cell and Developmental Biology, 28, 489-521. http://dx.doi.org/10.1146/annurev-cellbio-092910-154055.

Pietraszewska-Bogiel, A., Lefebvre, B., Koini, M.a., Klaus-Heisen, D., Takken, F. L. W., Geurts, R., ... Gadella, T. W. J. (2013). Interaction of Medicago truncatula lysin motif receptor-like kinases, NFP and LYK3, produced in Nicotiana benthamiana induces defence-like responses. PLoS One, 8(6), 16-18. http://dx.doi.org/10.1371/ journal.pone.0065055.

Pimprikar, P., Carbonnel, S., Paries, M., Katzer, K., Klingl, V., Bohmer, M. J. J., ... Gutjahr, C. (2016). A CCaMK-CYCLOPS-DELLA complex activates transcription of RAM1 to regulate arbuscule branching. Current Biology, 26(8), 987-998. http://dx.doi.org/10.1016/j.cub.2016.01.069.

Plett, J. M., Daguerre, Y., Wittulsky, S., Vayssières, A., Deveau, A., Melton, S. J., ... Martin, F. (2014). Effector MiSSP7 of the mutualistic fungus Laccaria bicolor stabilizes the populus JAZ6 protein and represses jasmonic acid (JA) responsive genes. Proceedings of the National Academy of Sciences of the United States of America, 111(22), 8299-8304. http://dx.doi.org/10.1073/pnas.1322671111.

Plett, J. M., \& Martin, F. (2011). Blurred boundaries: lifestyle lessons from ectomycorrhizal fungal genomes. Trends in Genetics, 27(1), 14-22. http://dx.doi.org/10.1016/ j.tig.2010.10.005.

Plett, J. M., \& Martin, F. (2012). Poplar root exudates contain compounds that induce the expression of MiSSP7 in Laccaria bicolor. Plant Signaling and Behavior, 7(1), 12-15. http://dx.doi.org/10.4161/psb.7.1.18357.

Radutoiu, S., Madsen, L. H., Madsen, E. B., Felle, H. H., Umehara, Y., Gronlund, M., ... Stougaard, J. (2003). Plant recognition of symbiotic bacteria requires two LysM receptor-like kinases. Nature, 425(6958), 585-592. http://dx.doi.org/ 10.1038/nature02039.

Rasmussen, S. R., Füchtbauer, W., Novero, M., Volpe, V., Malkov, N., Genre, A., ... Radutoiu, S. (May 2016). Intraradical colonization by arbuscular mycorrhizal fungi triggers induction of a lipochitooligosaccharide receptor. Scientific Reports, 6, 29733. http://dx.doi.org/10.1038/srep29733.

Reddy, P. M., María, M. R., \& Soto, D. L. D. (2007). Flavonoids as signaling molecules and regulators of root nodule development. Dynamic Soil, Dynamic Plant, Global Sci.

Redecker, D., Kodner, R., \& Graham, L. E. (2000). Glomalean fungi from the Ordovician. Science, 289(5486), 1920-1921. http://dx.doi.org/10.1126/science.289.5486.1920.

Redecker, D., Schüßler, A., Stockinger, H., Stürmer, S. L., Morton, J. B., \& Walker, C. (2013). An evidence-based consensus for the classification of arbuscular mycorrhizal fungi (Glomeromycota). Mycorrhiza, 23, 515-531. http://dx.doi.org/10.1007/ s00572-013-0486-y.

Remigi, P., Zhu, J., Young, J. P. W., \& Masson-Boivin, C. (2015). Symbiosis within symbiosis: evolving nitrogen-fixing legume symbionts. Trends in Microbiology. http:// dx.doi.org/10.1016/j.tim.2015.10.007.

Remy, W., Taylor, T. N., Hass, H., \& Kerp, H. (December 1994). Four hundred-millionyear-old vesicular arbuscular mycorrhizae. Proceedings of the National Academy of Sciences of the United States of America, 91, 11841-11843. http://dx.doi.org/10.1073/ pnas.91.25.11841.

Rey, T., Chatterjee, A., Buttay, M., Toulotte, J., \& Schornack, S. (2015). Medicago truncatula symbiosis mutants affected in the interaction with a biotrophic root pathogen. The New Phytologist, 206, 497-500. http://dx.doi.org/10.1111/nph.13233. 
Rey, T., Nars, A., Bonhomme, M., Bottin, A., Huguet, S., Balzergue, S., ... Jacquet, C. (2013). NFP, a LysM protein controlling Nod factor perception, also intervenes in Medicago truncatula resistance to pathogens. The New Phytologist, 198, 875-886. http:// dx.doi.org/10.1111/nph.12198.

Sayed, W. F., \& Wheeler, C. T. (1999). Effect of the flavonoid quercetin on culture and isolation of Frankia from Casuarina root nodules. Folia Microbiologica, 44(1), 59-62. http://dx.doi.org/10.1007/BF02816223.

Scaffidi, A., Waters, M. T., Sun, Y. K., Skelton, B. W., Dixon, K. W., Ghisalberti, E. L., ... Smith, S. M. (2014). Strigolactone hormones and their stereoisomers signal through two related receptor proteins to induce different physiological responses in arabidopsis. Plant Physiology, 165(3), 1221-1232. http://dx.doi.org/ 10.1104/pp.114.240036.

Schauser, L., Roussis, A., Stiller, J., \& Stougaard, J. (1999). A plant regulator controlling development of symbiotic root nodules. Nature, 402(6758), 191-195. Retrieved from $<$ Go to ISI > ://000083716400053.

Shimizu, T., Nakano, T., Takamizawa, D., Desaki, Y., Ishii-Minami, N., Nishizawa, Y.,... Shibuya, N. (2010). Two LysM receptor molecules, CEBiP and OsCERK1, cooperatively regulate chitin elicitor signaling in rice. Plant Journal, 64, 204-214. http://dx.doi.org/10.1111/j.1365-313X.2010.04324.x.

Simon, L., Bousquet, J., Levesque, R. C., \& Lalonde, M. (1993). Origin and diversification of endomycorrhizal fungi and coincidence with vascular land plants. Nature, 365, 67-69.

Smith, S. E., \& Read, D. (2008). Mycorrhizal symbiosis. (3rd ed.). New York: Academic Press. http://dx.doi.org/10.1016/B978-012370526-6.50015-5.

Soto, M. J., Fernández-Aparicio, M., Castellanos-Morales, V., García-Garrido, J. M., Ocampo, J.a., Delgado, M. J., \& Vierheilig, H. (2010). First indications for the involvement of strigolactones on nodule formation in alfalfa (Medicago sativa). Soil Biology and Biochemistry, 42(2), 383-385. http://dx.doi.org/10.1016/j.soilbio.2009.11.007.

Soyano, T., \& Hayashi, M. (2014). Transcriptional networks leading to symbiotic nodule organogenesis. Current Opinion in Plant Biology, 20, 146-154. http://dx.doi.org/ 10.1016/j.pbi.2014.07.010.

Steinkellner, S., Lendzemo, V., Langer, I., Schweiger, P., Khaosaad, T., Toussaint, J. P., \& Vierheilig, H. (2007). Flavonoids and strigolactones in root exudates as signals in symbiotic and pathogenic plant-fungus interactions. Molecules, 12(7), 1290-1306. http://dx.doi.org/10.3390/12071290.

Sun, J., Miller, J. B., Granqvist, E., Wiley-Kalil, A., Gobbato, E., Maillet, F.,... Oldroyd, G. E. D. (March 2015). Activation of symbiosis signaling by arbuscular mycorrhizal fungi in legumes and rice. The Plant Cell, 27, 823-838. http:// dx.doi.org/10.1105/tpc.114.131326.

Sutton, J. M., Lea, E. J., \& Downie, J. A. (1994). The nodulation-signaling protein NodO from Rhizobium leguminosarum biovar viciae forms ion channels in membranes. Proceedings of the National Academy of Sciences of the United States of America, 91(21), 9990-9994. Retrieved from http://www.ncbi.nlm.nih.gov/pubmed/ 7524090 .

Tanaka, K., Cho, S. H., Lee, H., Pham, A. Q., Batek, J. M., Cui, S., ... Stacey, G. (2015). Effect of lipo-chitooligosaccharide on early growth of $\mathrm{C}_{4}$ grass seedlings. Journal of Experimental Botany, 66(19), 5727-5738. http://dx.doi.org/10.1093/jxb/erv260.

Tedersoo, L., May, T. W., \& Smith, M. E. (2010). Ectomycorrhizal lifestyle in fungi: global diversity, distribution, and evolution of phylogenetic lineages. Mycorrhiza, 20(4), 217-263. http://dx.doi.org/10.1007/s00572-009-0274-x.

Tedersoo, L., \& Smith, M. E. (2013). Lineages of ectomycorrhizal fungi revisited: foraging strategies and novel lineages revealed by sequences from belowground. Fungal Biology Reviews, 27(3-4), 83-99. http://dx.doi.org/10.1016/j.fbr.2013.09.001. 
Tisa, L. S., Beauchemin, N., Gtari, M., Sen, A., \& Wall, L. G. (2013). What stories can the Frankia genomes start to tell us? Journal of Biosciences, 38(4), 719-726. http://dx.doi.org/ 10.1007/s12038-013-9364-1.

Tisserant, E., Malbreil, M., Kuo, A., Kohler, A., Symeonidi, A., Balestrini, R., ... Martin, F. (2013). Genome of an arbuscular mycorrhizal fungus provides insight into the oldest plant symbiosis. Proceedings of the National Academy of Sciences of the United States of America, 110(50), 20117-20122. http://dx.doi.org/10.1073/pnas.1313452110.

Tsai, S. M., \& Phillips, D. A. (1991). Flavonoids released naturally from alfalfa promote development of symbiotic glomus spores in vitro. Applied and Environmental Microbiology, 57(5), 1485-1488.

Tsuzuki, S., Handa, Y., Takeda, N., \& Kawaguchi, M. (2016). Strigolactone-induced putative secreted protein 1 is required for the establishment of symbiosis by the arbuscular mycorrhizal fungus Rhizophagus irregularis. Molecular Plant-Microbe Interactions, 29(4), 1-59. http://dx.doi.org/10.1094/MPMI-10-15-0234-R.

Van Loon, L. C. (2007). Plant responses to plant growth-promoting rhizobacteria. European Journal of Plant Pathology, 119(3), 243-254. http://dx.doi.org/10.1007/s10658-0079165-1.

Van Zeijl, A., Liu, W., Xiao, T.ting, Kohlen, W., Yang, W.-C., Bisseling, T., \& Geurts, R. R. (2015). The strigolactone biosynthesis gene DWARF27 is co-opted in rhizobium symbiosis. BMC Plant Biology, 15(1), 260. http://dx.doi.org/10.1186/ s12870-015-0651-x.

Vayssières, A., Pěnčík, A., Felten, J., Kohler, A., Ljung, K., Martin, F. M., \& Legue, V. (September 2015). Development of the Populus-Laccaria bicolor ectomycorrhiza modifies root auxin metabolism, signalling and response. Plant Physiology, 169, 114.255620. http://dx.doi.org/10.1104/pp.114.255620.

Vogel, J. T., Walter, M. H., Giavalisco, P., Lytovchenko, A., Kohlen, W., Charnikhova, T., ... Klee, H. J. (2010). SlCCD7 controls strigolactone biosynthesis, shoot branching and mycorrhiza-induced apocarotenoid formation in tomato. The Plant Journal: For Cell and Molecular Biology, 61(2), 300-311. http://dx.doi.org/10.1111/ j.1365-313X.2009.04056.x.

Wang, B., \& Qiu, Y. L. (2006). Phylogenetic distribution and evolution of mycorrhizas in land plants. Mycorrhiza, 16(5), 299-363. http://dx.doi.org/10.1007/s00572-0050033-6.

Wasson, A. P., Pellerone, F. I., \& Mathesius, U. (2006). Silencing the flavonoid pathway in Medicago truncatula inhibits root nodule formation and prevents auxin transport regulation by rhizobia. The Plant Cell, 18(7), 1617-1629. http://dx.doi.org/10.1105/ tpc.105.038232.

Weston, L. A., \& Mathesius, U. (2013). Flavonoids: their structure, biosynthesis and role in the rhizosphere, including allelopathy. Journal of Chemical Ecology, 39(2), 283-297. http://dx.doi.org/10.1007/s10886-013-0248-5.

Wild, M., Davière, J.-M., Cheminant, S., Regnault, T., Baumberger, N., Heintz, D., ... Achard, P. (2012). The arabidopsis DELLA RGA-LIKE3 is a direct target of MYC2 and modulates jasmonate signaling responses. The Plant Cell, 24, 3307-3319. http://dx.doi.org/10.1105/tpc.112.101428.

Yang, D.-L., Yao, J., Mei, C.-S., Tong, X.-H., Zeng, L.-J., Li, Q., ... He, S. Y. (2012). Plant hormone jasmonate prioritizes defence over growth by interfering with gibberellin signaling cascade. Proceedings of the National Academy of Sciences of the United States of America, 109(19), E1192-E1200. http://dx.doi.org/10.1073/pnas.1201616109.

Yoshida, S., Kameoka, H., Tempo, M., Akiyama, K., Umehara, M., Yamaguchi, S., ... Shirasu, K. (2012). The D3 F-box protein is a key component in host strigolactone responses essential for arbuscular mycorrhizal symbiosis. The New Phytologist, 196(4), 1208-1216. http://dx.doi.org/10.1111/j.1469-8137.2012.04339.x. 
Young, N. D., Debellé, F., Oldroyd, G. E. D., Geurts, R., Cannon, S. B., Udvardi, M. K., ... Roe, B. A. (2011). The Medicago genome provides insight into the evolution of rhizobial symbioses. Nature, 480(7378), 520-524. http://dx.doi.org/ 10.1038/nature10625.

Yu, N., Luo, D., Zhang, X., Liu, J. J., Wang, W., Jin, Y., ... Wang, E. (2014). A DELLA protein complex controls the arbuscular mycorrhizal symbiosis in plants. Cell Research, 24(1), 130-133. http://dx.doi.org/10.1038/cr.2013.167.

Zhang, X., Dong, W., Sun, J., Feng, F., Deng, Y., He, Z., ... Wang, E. (2015). The receptor kinase CERK1 has dual functions in symbiosis and immunity signalling. The Plant Journal, 81(2), 258-267. http://dx.doi.org/10.1111/tpj.12723.

Zhang, Y., van Dijk, A. D. J., Scaffidi, A., Flematti, G. R., Hofmann, M., Charnikhova, T.,... Bouwmeester, H. J. (2014). Rice cytochrome P450 MAX1 homologs catalyze distinct steps in strigolactone biosynthesis. Nature Chemical Biology, 10(12), 1028-1033. http://dx.doi.org/10.1038/nchembio.1660.

Zhao, L.-H., Zhou, X. E., Yi, W., Wu, Z., Liu, Y., Kang, Y.,... Xu, H. E. (2015). Destabilization of strigolactone receptor DWARF14 by binding of ligand and E3-ligase signaling effector DWARF3. Cell Research, 25(11), 1219-1236. http://dx.doi.org/ 10.1038/cr.2015.122.

Zuanazzi, J. A. S., Clergeot, P. H., Quirion, J. C., Husson, H. P., Kondorosi, A., \& Ratet, P. (1998). Production of Sinorhizobium meliloti nod gene activator and repressor flavonoids from Medicago sativa roots. Molecular Plant-Microbe Interactions, 11(8), 784-794. http:// dx.doi.org/10.1094/MPMI.1998.11.8.784. 